CURSO DE ESPECIALIZAÇÃO EM DESENVOLVIMENTO HUMANO, EDUCAÇÃO E INCLUSÃO ESCOLAR - UAB/UnB

\title{
A MEDIAÇÃO AFETIVA NO PROCESSO DE INCLUSÃO ESCOLAR DO ALUNO COM TRANSTORNO GLOBAL DO DESENVOLVIMENTO \\ - TGD - um estudo de caso.
}

Érika Goulart Araújo

ORIENTADORA: Prof ${ }^{a}$. Esp. Geane de Jesus Silva 


\section{A MEDIAÇÃO AFETIVA NO PROCESSO DE INCLUSÃO ESCOLAR DO ALUNO COM TRANSTORNO GLOBAL DO DESENVOLVIMENTO - TGD - um estudo de caso.}

Monografia apresentada ao Curso de Especialização em Desenvolvimento Humano, Educação e Inclusão, da Faculdade UAB/UNB - Pólo de Ceilândia. Orientadora: Prof ${ }^{a}$. Esp. Geane de Jesus Silva. 


\title{
TERMO DE APROVAÇÃO
}

\author{
Érika Goulart Araújo
}

\section{A MEDIAÇÃO AFETIVA NO PROCESSO DE INCLUSÃO ESCOLAR DO ALUNO COM TRANSTORNO GLOBAL DO DESENVOLVIMENTO - TGD - um estudo de caso.}

Monografia aprovada como requisito parcial para obtenção do grau de Especialista do Curso de Especialização em Desenvolvimento Humano, Educação e Inclusão Escolar - UAB/UnB. Apresentação ocorrida em 16/04/2011.

Aprovada pela banca formada pelos professores:

Prof $^{a}$. Esp. GEANE DE JESUS SILVA (Orientador)

Dra. SILMARA CARINA DORNELAS MUNHOZ (Examinador)

ÉRIKA GOULART ARAÚJO (Cursista) 
À minha família onde me aninho.

À minha mãe, companheira e amiga de longas madrugadas de estudo. A meu amigo, Sérgio que em meio a tantas dificuldades pode me ajudar a crescer. 


\section{AGRADECIMENTOS}

A Força Divina que me protege e ma lança à frente conseguindo alçar vôo.

À orientadora Geane pela forma atenciosa com a qual me orientou e acompanhou cada passo desta pesquisa. Por seu profissionalismo e conhecimentos alicerçados a profunda gentileza humana.

Às Professoras Ângela, Marta e Nilcéia pela enorme contribuição na construção de meus conhecimentos e pela abertura de seus corações para esta pesquisa.

Aos alunos que acolhem a preciosa Aline e a faz feliz.

A aluna Aline que mesmo em seu mundo nos ensina que o mais importante é o amor. Pelo seu abraço gostoso e a meiguice de sua voz que me acalma a alma.

Pelo acolhimento, agradeço aos gestores, professores e funcionários da escola onde a pesquisa se realizou.

Ao corpo docente Curso de Especialização em Desenvolvimento Humano, Educação e Inclusão, da Faculdade UAB/UNB - Pólo de Ceilândia desenvolvido pela Universidade de Brasília pela oportunização e disponibilização de suas experiências.

Aos meus colegas de turma pelas conversas, sugestões e incentivos on-line de grande enriquecimento. 


\section{RESUMO}

O presente estudo enfoca questões atuais sobre uma particularidade da inclusão, constitui-se num estudo de caso sobre o papel da mediação afetiva no processo de inclusão de um aluno com Transtorno Global do Desenvolvimento, compreendendo como a mediação afetiva no contexto escolar pode contribuir para o processo de inclusão educacional de um aluno com TGD. Para isso, foi necessário identificar a contribuição da mediação entre professor e aluno, observar a interação entre o aluno e seus pares, as limitações específicas e sua relação com as trocas afetivas e a identificação da mediação pedagógica que o professor lança mão para a interação do aluno com TGD. O estudo utilizou como referencial teórico os trabalhos dos teóricos como: Piaget, Vygotsky e Wallon. Empregou na metodologia a abordagem qualitativa de pesquisa, utilizando como instrumentos de coleta de dados as entrevistas realizadas com professores as observações do aluno no ambiente escolar e a análise de documento, sendo discutidos à luz do caráter interpretativo-construtivo. A contribuição dessas reflexões possibilita reelaborar questões sobre o papel da mediação afetiva no processo de inclusão escolar indicando sua eficácia quando resguardada a individualidade do aluno com necessidades educacionais especiais.

Palavras-chave: Inclusão, mediação afetiva, transtorno global do desenvolvimento. 


\section{SUMÁRIO}

RESUMO vi

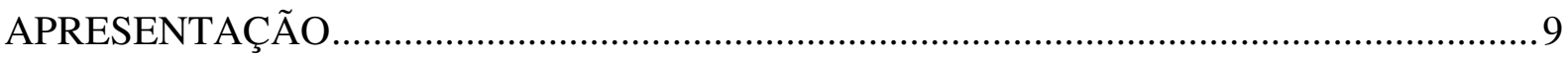

I - EDUCAÇÃO: UMA RELAÇÃO ENTRE AFETIVIDADE E INTERAÇÃO SOCIAL .. 11

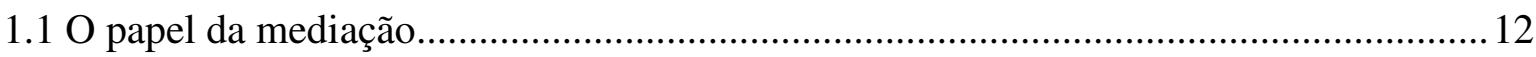

1.2 Educação para afetividade - o lugar do afeto nas relações sociais ................................ 15

II - EDUCAÇÃO INCLUSIVA - ALTERIDADE E APRENDIZAGEM DO ALUNO COM TRANSTORNO GLOBAL DO DESENVOLVIMENTO - TGD ......................................... 18

2.1 Escola e o Paradoxo: Inclusão x Exclusão Educacional..................................................20

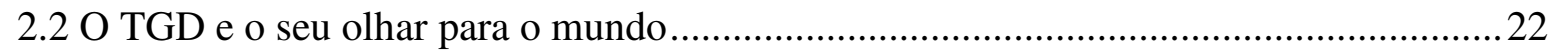

2.2.1 O papel do outro no processo de aprendizagem do TGD .....................................24

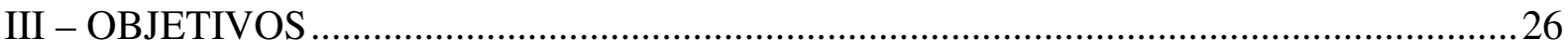

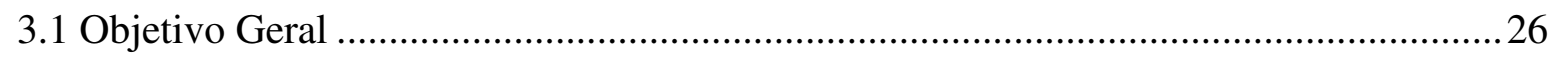

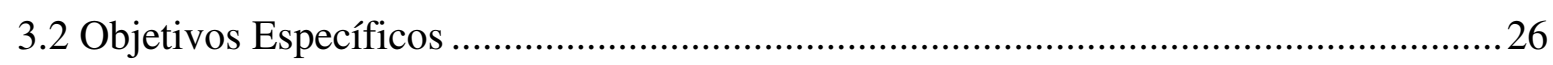

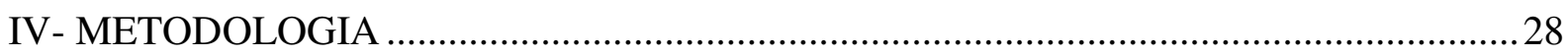

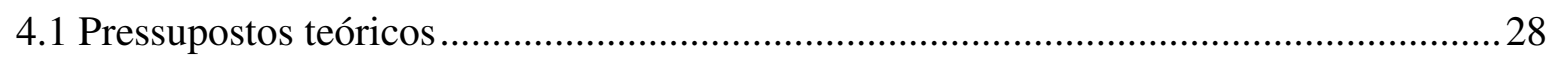

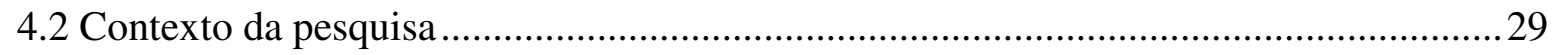

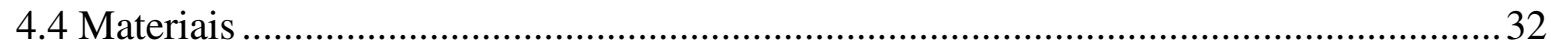

4.5 Instrumentos de construção de dados ...................................................................... 32

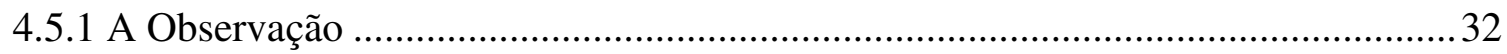

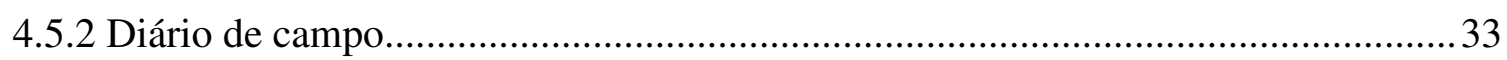

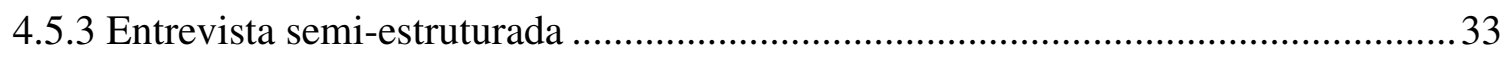

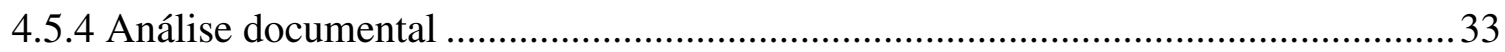

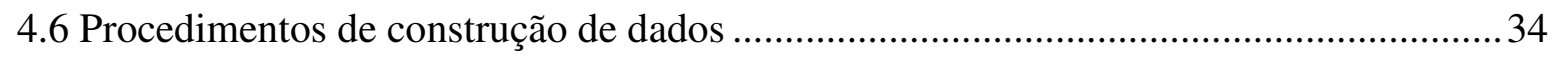

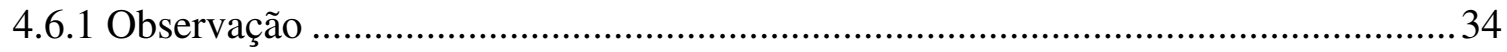

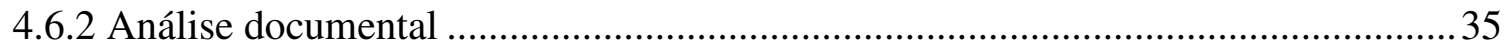

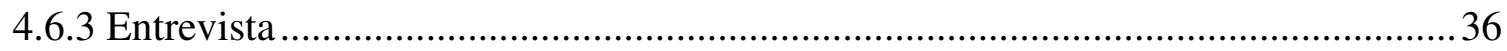

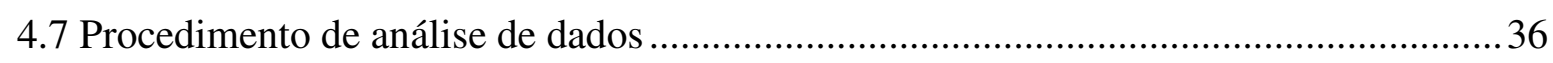

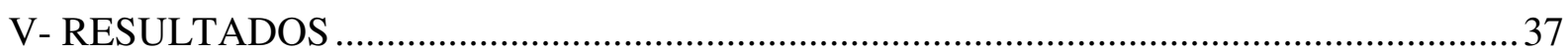

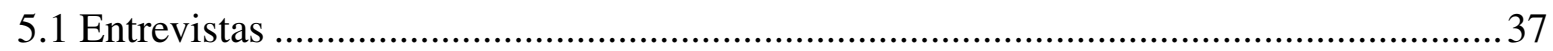

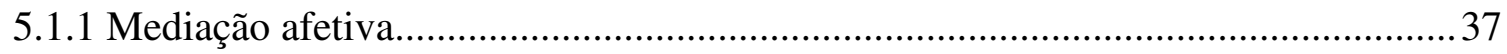

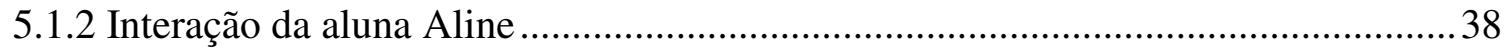

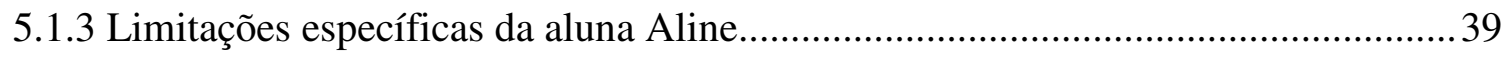

5.1.4 A participação do outro no processo de inclusão ................................................ 40

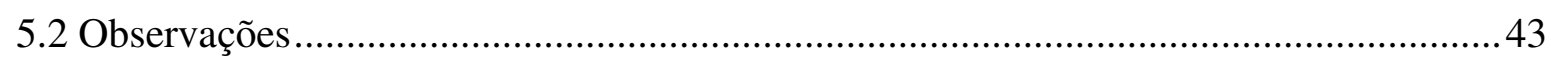

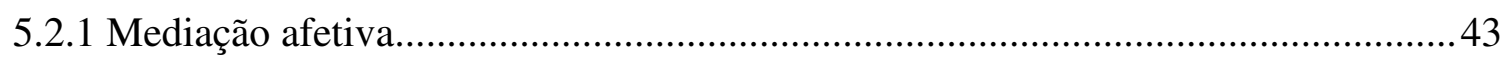

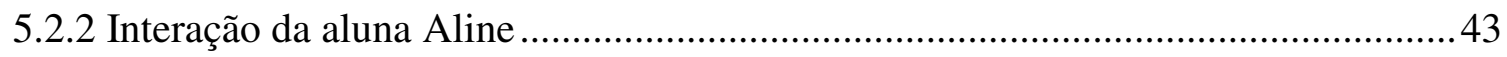




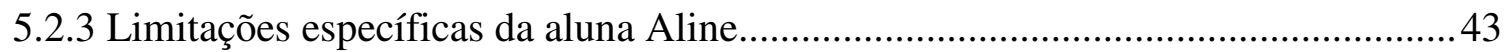

5.2.4 A participação do outro no processo de inclusão ...................................................4

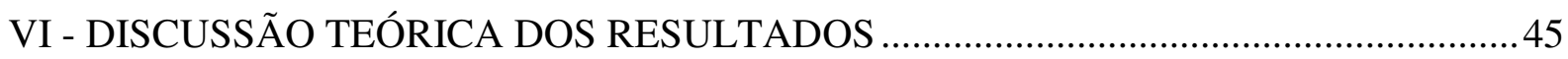

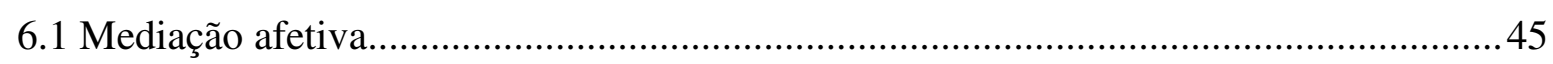

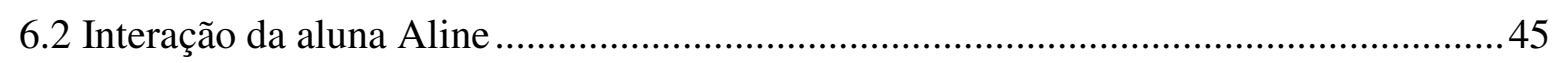

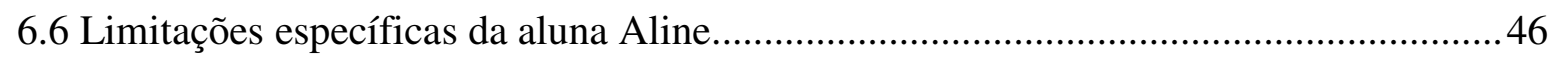

6.7 A participação do outro no processo de inclusão .......................................................... 48

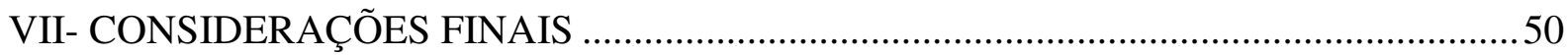

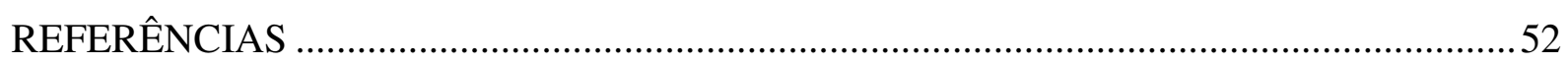

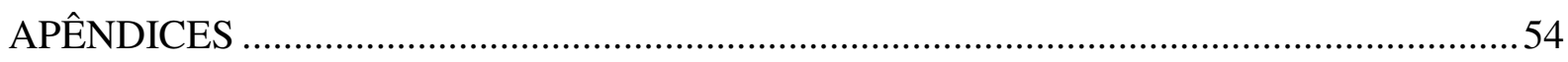

Apêndice A - Roteiro de Entrevista - Docente..............................................................55

Apêndice B - Roteiro de Observação.............................................................................56

Apêndice C - Roteiro de Observação - Aluno TGD ........................................................57

Apêndice D - Roteiro de Observação - Aspectos físicos e estruturais .................................58

Apêndice E - Roteiro de Observação - Material Pedagógico................................................59

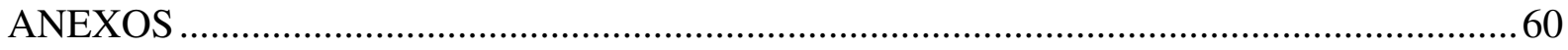

Anexo A - Termo de Consentimento Livre e Esclarecido - Pais .......................................61

Anexo B - Termo de Consentimento Livre e Esclarecido - Professores ............................62 


\section{APRESENTAÇÃO}

O cerne da pesquisa, ora apresentada, levanta uma inquietação científico-pedagógica que leva a um estudo de caso evidenciado no contexto de uma escola pública do Distrito Federal. Para tanto, a situação de estudo, situa-se no contexto escolar de uma criança do sexo feminino diagnosticada com Transtorno Global do Desenvolvimento - TGD portadora de autismo atípico, matriculada no $2^{\circ}$ Ano do Ensino Fundamental de nove anos de uma instituição na rede pública de ensino.

O critério de seleção da situação de estudo desse trabalho de pesquisa se deu com base na angústia suscitada com a minha prática. Na qualidade de Pedagoga e Orientadora Educacional a mais de 15 anos, venho acompanhando casos específicos de TGD, o que me credenciou ao longo desses anos, lançar mão de diversificado material pedagógico que trata do assunto. Além de uma grande motivação em conhecer e poder contribuir com a inserção da criança especial num contexto escolar que favoreça seu desenvolvimento psicossocial. O tema mexe com o meu senso ético e profissional, pois, acompanho o caso em estudo há mais de quatro anos.

Mediante tais inquietações, a pesquisa foi guiada na busca por resposta à seguinte problematização: Até que ponto a mediação afetiva presente no contexto escolar contribuem ou não com o processo de inclusão educacional? Em outras palavras, a investigação especula sobre até que ponto as dificuldades do desenvolvimento cognitivo de um TGD poderão ser dirimidas ou mesmo sanadas a partir da mediação afetiva dentro de um processo de inclusão educacional.

A partir de tal indagação, formulou-se diversificadas hipóteses na tentativa de mensurar a relativização da capacidade cognitiva dessa criança, envolvendo os aspectos psicossociais, afetivos, culturais, históricos e contextuais. A tal contribuição, entende-se que, vai bem além do ramo pedagógico, pois, envolve a interdisciplinaridade entre as ciências psicologia, neurociência, sociologia, pedagogia, filosofia, dentre outras.

Portanto, o objetivo principal incube-se em compreender como a mediação afetiva pode contribuir para o processo de inclusão educacional de um aluno com TGD.

Com base na meta geral, o que se objetiva especificamente é: a) identificar a contribuição da mediação afetiva entre professor e aluno no processo de inclusão educacional; b) observar como se dá a interação do aluno TGD com seus pares e até que ponto isso 
contribui com o processo de inclusão do mesmo; c) verificar até que ponto as limitações específicas do TGD atrapalham as trocas afetivas entre o aluno que apresenta o transtorno e seu ambiente; d) identificar qual a mediação pedagógica o docente utiliza para possibilitar a interação do TGD com o ambiente e o outro.

O alcance de tais objetivos somente foi possível pelo fato do trabalho de campo ter sido feito por meio de uma abordagem com profissionais que já tinham experiências vivenciadas em sala de aula e o que o professor vem trabalhando a capacidade cognitiva do aluno com TGD, na tentativa de minimizar deficiências de aprendizagem e maximizar a sua capacidade intelectiva e social. Para chegar-se a tais resultados, empregou-se a abordagem qualitativa de pesquisa, por meio de coleta de dados através de entrevistas com os profissionais e observação direta e indireta da realidade do contexto escolar da aluna.

O trabalho em questão está embasado teoricamente nos principais teóricos que tratam do assunto, tais como: Vigotsky, Wallon e Piaget. E está organizado em cinco capítulos, dispostos da seguinte maneira: I - Fundamentação Teórica: Ampliando os Horizontes; traz a parte da revisão bibliográfica sobre temáticas que elucidam a questão da afetividade, da interação social e o do ensino-aprendizagem do ANEE-TGD; II - Objetivos: apontando as diretivas; explica com mais detalhe a finalidade deste trabalho; III - Metodologia: laboratório qualitativo, que retrata a importância da epistemologia qualitativa pertinente a esta pesquisa, a apresentação da instituição e dos sujeitos participantes. Constam ainda do laboratório qualitativo os procedimentos de coleta e tratamento dos dados; IV - Resultados e Discussão apresentam os dados relevantes e em seguida uma discussão estabelecendo relação entre o trabalho empírico e a base teórica assumida na pesquisa; V - Considerações Finais: A serviço de um aluno muito especial, que trazem a recapitulação sintética dos resultados e da discussão apresentando possíveis caminhos e conclusões obtidas com esse estudopesquisa. 


\section{I - EDUCAÇÃO: UMA RELAÇÃO ENTRE AFETIVIDADE E INTERAÇÃO SOCIAL}

Partindo-se de uma definição bem estruturada, abre-se um leque de possibilidades de reflexão sobre o conceito de educação o qual fica praticamente indissociável do conceito de interação social, como a seguir:

Educação é a transmissão de cultura socializada ao interesse de um sujeito humano, ao qual por meio de assimilação se traduzirá em aptidões primariamente sociais. Ou de uma forma mais completa: Educação é a transmissão, por parte da sociedade, dos conhecimentos culturais da cultura socializada, perante a assimilação de um interesse ou energia social do indivíduo que traduzirá as informações transmitidas em aptidões primordialmente sociais que lhe permitam incorporar-se como membro útil nessa sociedade que precisa dele para continuar-se. (CIRIGLIANO, 1972, p. 53).

Como visto, não há como dissociar o processo educacional do processo de sociabilização. Um está interligado ao outro. Portanto, a interação social é parte integrante da educação que, por sua vez, precede a inclusão educacional.

Na teoria walloniana, conforme Galvão (1995, p.91a), a interação social ganha a seguinte perspectiva, conforme o seguinte trecho:

(...) a ideia de uma personalidade que se forma isolada da sociedade é inconcebível para a perspectiva walloniana, segundo o qual é na interação e no confronto com o outro que se forma o indivíduo. Wallon considera, portanto, que a educação deve, obrigatoriamente, integrar, à sua prática e aos seus objetivos, essas duas dimensões, a social e a individual: deve, portanto, atender simultaneamente à formação do indivíduo e à da sociedade.

Tal perspectiva revela a necessidade do indivíduo em relação ao social e vice-versa. Pois, a sociabilização é parte natural da evolução humana, uma vez, que o ser humano nasce dentro de uma família consanguinea e, depois, ao se inserir na sociedade, constitui família e assim por diante. Trata-se de uma necessidade biológica humana. E o mesmo ocorre nas questões de interações educacionais e sociais.

Essa percepção é de suma importância quando se refere à questão de interação social, onde Vygotsky avalia da seguinte maneira:

O termo interação social está intimamente ligado à proposta de Vygotsky, na medida em que este autor adota uma visão de homem que é essencialmente social: é na relação com o próximo, numa atividade prática comum, que este, por intermédio da linguagem, acaba por se constituir e se desenvolver enquanto sujeito. Desta maneira. Vygotsky acredita que o ser humano, diferentemente do animal, não se encontra 
limitado a sua própria experiência pessoal e/ou a suas próprias reflexões. Ao contrário, a experiência individual alimenta-se, expande-se e aprofunda-se em especial graças à apropriação da experiência social que é veiculada pela linguagem. Este legado das gerações precedentes é, pois, transmitido pela linguagem nas relações sociais entre os homens, de tal forma que as observações e conhecimentos de todos os seres humanos convertem-se, assim, em propriedade de cada um ou podem chegar a converter-se em tal. (apud DAVIS, SILVA \& ESPÓSITO, 1989, p. 50):

Assim, fica patenteada mais uma vez a necessidade da interação educação e interação social, por mais um motivo: a linguagem. Pois, todo ser humano sente necessidade de comunicar-se, seja pelo processo de comunicação verbal ou não verbal, escrita ou oral. Pressupõe-se que se trata de uma necessidade humana, evoluir individualmente por meio da sociedade, para ela e por ela somar-se.

\title{
1.1 O papel da mediação
}

Em se tratando de relações sociais, entra em cena, a relevância da mediação para a qualidade desse processo. Etimologicamente a palavra mediação vem do latim Mediari de Medius - meio, o que significa "intervir, colocar-se entre duas partes".

Assim, esse fenômeno é bem retratado por Rego ao refletir Vygotsky sobre as raízes histórico-sociais do desenvolvimento humano e a questão da mediação, da seguinte maneira:

\begin{abstract}
Compreender a questão da mediação, que caracteriza a relação do homem com o mundo e com os outros homens é de fundamental importância justamente porque é através deste processo que as funções psicológicas superiores, especificamente humanas, se desenvolvem. Vygotsky distingue dois elementos básicos responsáveis por essa mediação: o instrumento, que tem a função de regular as ações sobre os objetos e o signo, que regula as ações sobre o psiquismo das pessoas. (REGO, 1995, p. 50).
\end{abstract}

Nesse contexto, no âmbito da escola, a mediação se configura por meio da intervenção pedagógica intencional que nada mais é do que a mediação do outro, uma interferência do professor, por objetivar a formação psíquica e social da criança, estabelecendo critérios para a aprendizagem em função da construção do conhecimento.

Partindo dessa questão, refletir sobre a mediação no contexto escolar, requer um enfoque teórico que considere os aspectos individuais, sociais e culturais. Nesse sentido, as teorias construtivistas e sociogenéticas, quando combinadas, geram uma simbiose ideológica,

$1 \quad$ ORIGEM $\quad$ DA $\quad$ PALVARA - Site $\quad$ de $\quad$ Etimologia. $\quad$ Disponível em:


que atende a essa necessidade, sobre essa fusão, Maciel \& Raposo (2010, p.75) apresentam a seguinte explicação:

Tal perspectiva teórica, que vem sendo chamada de abordagem sociocultural construtivista, (ver Branco; Pessina; Flores; Salomão 2004) parte do ponto de vista sociogenético, de acordo com o qual todo o processo psicológico humano é social por natureza. Defende que o desenvolvimento humano ocorre por meio da interação dialética entre processo de canalização cultural e de constituição do indivíduo, enquanto sujeito ativo e co-participante do seu próprio desenvolvimento. Por outras palavras, processos de aprendizagem desenvolvem-se em contextos sociais que são mediados por atos de co-construção. (Grifo das autoras).

Assim, essas teorias, construtivista e sociogenética, se complementam, pois enquanto a primeira explora a complexidade subjetiva dos aspectos psicológicos e da autonomia do ser, a segunda trata da sociabilização. Ou seja, é uma questão dialética nos princípios e que caminham juntas, privilegiando o aspecto individual, psíquico e a integração social.

A partir de tal perspectiva, torna-se necessário refletir sobre o papel do outro o qual integra todo o processo de desenvolvimento do ser, no intuito exclusivo de inserção social por meio da educação. Sabe-se que o processo da aprendizagem quando assume o aspecto social é de responsabilidade de quem se propõe a ensinar, neste caso, assume o papel do outro social, estabelecendo-se, então, a dita zona de desenvolvimento proximal a qual retrata a concepção de que os processos de desenvolvimento e aprendizagem humanos são exclusivamente e inclusivamente sociais.

A tarefa do outro é estritamente social, não comportando o individualismo, muito menos só a interiorização do ser. Vygotsky mostra-se preocupado com a questão da exteriorização, entende a função psíquica e as relações intrapsíquicas. O importante é saber lidar com as relações de interação social.

Nesse caso, segundo Galvão (1995, p. 50) citando Wallon:

O estado inicial da consciência pode ser comparado a uma nebulosa, uma massa
difusa, na qual confundem-se o próprio sujeito e a realidade exterior. O recém-
nascido não se percebe como indivíduo diferenciado (...). Até que a criança saiba
identificar sua personalidade e a dos outros, correspondendo a primeira ao eu e as
segundas à categoria do não-eu, encontra-se num estado de dispersão e
indiferenciação, percebendo-se como que fundida ao outro e aderia às situações e
circunstâncias. Portanto, o sentido do processo de socialização é de crescente
individuação

Sustentando a discussão sobre a função do outro social, torna-se importante destacar, entre os vários pontos da teoria vygotskyniana, dois em especial: a constituição social do homem e a zona de desenvolvimento proximal. 
O princípio da psicologia histórico-social coloca que a constituição do homem (ser humano) se dá por meio das relações estabelecidas com os outros. Quer dizer, assim que nasce já se estabelece uma relação de dependência de outrem, e de tal modo começa o processo histórico, primeiramente pela visão de mundo do outro e posteriormente, a visão pessoal sobre este mesmo mundo, vista sobre outro ângulo.

Valendo lembrar que nesse processo existem os fatores tempo e espaço dentro de um contexto histórico-social e espacial, ou seja, o momento em que se vive interligado a um processo histórico (cerceado de fatos e eventos) e história de outros (social) dentro de um determinado espaço e tempo cronológico. Tal construção histórica, com o seu processo histórico de vida e o histórico de vida de outras pessoas, acaba constituindo o chamado patrimônio cultural da humanidade. De onde nascem os valores (positivos ou negativos) que acabam por constituir e educar culturalmente o homem.

Destacando a zona de desenvolvimento proximal - ZDP, teoria desenvolvida por Vygotsky, refere-se a equidistância daquilo que uma criança seja capaz de aprender sozinha e o que necessita da intervenção de um adulto, uma relação entre o nível de desenvolvimento real e o seu potencial para aprender, entre aprendizagem e desenvolvimento inter-relacionais, um campo onde para a criança necessita de uma experiência do outro.

Vygotsky (1984, p. 97) conceitua a ZDP, assim:

[...] A distância entre o nível de desenvolvimento real, que se costuma determinar através da solução independente de problemas, e o nível de desenvolvimento potencial, determinado através da solução de problemas sob a orientação de um adulto ou em colaboração com companheiros mais capazes.

Esse é exatamente o papel do mediador, sendo sua função a mediação semiótica, que propõe uma explicação do desenvolvimento mental, enfatizando os processos distintos das funções interpsíquicas das intrapsíquicas, no processo de desenvolvimento dentro das relações de interações sociais.

Cabe salientar que para o desenvolvimento intelectivo do aluno, há que se observar que não basta apenas o desenvolvimento por si só, tem que haver resultados efetivos. A eficácia como atividade escolar empregando a ZDP é caracteristicamente de aplicabilidade social, visando o desenvolvimento humano, dentro do contexto escolar, sempre com o auxílio de um professor, facilitador, indutor, em outras palavras, mediador.

O importante é que nessa relação educador-educando haja uma interação, até que cheguem ao que Vygotsky (1984), salienta "zona em que se encontram as capacidades e habilidades potenciais, em amadurecimento". 
O fato é que o papel do mediador docente é explorar a ZDP em função da construção e formação do conhecimento dentro do processo de desenvolvimento do aluno, em um determinado contexto e envolve, ainda, um processo de interação social. Portanto, o professor tem o papel de facilitador, uma vez que o processo de construção do conhecimento se dá em nível intrapessoal, apesar de se trabalhar com uma classe heterogênea, vale a lei da dupla estimulação, conforme o gráfico esquemático:

Figura 1-

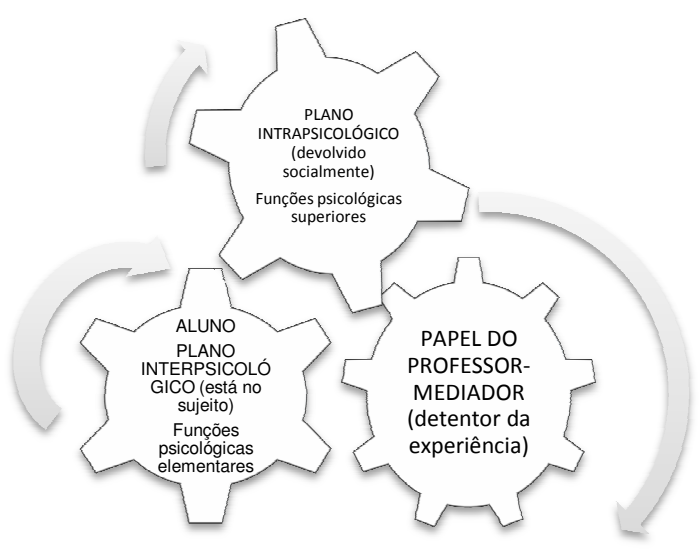

Fonte: Elaborado por ARAÚJO, G. Érika

Esse esquema demonstra claramente o processo de intervenção do educador, em sua função de conduzir (dupla estimulação) seu educando, por meio da mediação em prol da construção do conhecimento, ocorrendo dentro de seu grupo social e contextual, a passagem do estágio do interpsicológico para o intrapsicológico, no qual se manifesta o fenômeno de aprender e reconstruir, aspecto relevante para o processo da educação e interação social.

Por este lado,

O desenvolvimento pleno do ser humano depende do aprendizado que realiza num determinado grupo cultural, a partir da interação com outros indivíduos da sua espécie. (...) A criança só aprenderá a falar se pertencer a uma comunidade de falantes, ou seja, as condições orgânicas (possuir o aparelho fonador), embora necessárias, não são suficientes para que o indivíduo adquira a linguagem. (REGO, 1985, p. 71).

\subsection{Educação para afetividade - o lugar do afeto nas relações sociais}


Afeto e cognição são características do ser humano e são indissociáveis. Em uma visão holística do ser, cognição e afetividade constitui o homem a partir do seu todo, indo contra fragmentação do sujeito.

No âmbito da educação, tal perspectiva é necessária, devido a multiplicidade de seres heterogêneos. Nesse sentido, tanto a cognição quanto a emoção são elementos que devem ser contemplados nas práticas educativas.

Vygotsky, Wallon e Piaget, apresentam cada um dentro de suas especificidades, aspectos conceituais sobre a temática que podem contribuir com a compreensão dessa questão.

Assim, Wallon centra-se nos propósitos da afetividade, como bem retrata o trecho abaixo:

\begin{abstract}
Na psicogenética de Henri Wallon, a dimensão afetiva ocupa lugar central, tanto do ponto de vista da construção da pessoa quanto do conhecimento. Ambos se iniciam num período que ele denomina impulsivo-emocional e se estende ao longo do primeiro ano da vida. Neste momento a afetividade reduz-se praticamente às manifestações fisiológicas da emoção, que constitui, portanto, o ponto de partida do psiquismo. (TAILLE, OLIVEIRA \& DANTAS, 1995, p. 75a).
\end{abstract}

Já em relação à cognição, Vygostky, discute a relevância da "mentalidade dos processos psicológicos superiores no funcionamento típico da espécie humana" o que se processa através do "papel dos instrumentos e símbolos, culturalmente desenvolvidos e internalizados pelo indivíduo no processo da mediação entre sujeito e objeto de conhecimento" o que é explicado com base na "questão dos processos metacogntivos". (apud, TAILLE, OLIVEIRA \& DANTAS, 1995, p. 75).

A completude entre o ser racional e emotivo, entre "razões e emoções" tem muito do processo de construção social e inserção do homem por meio da educação motivada pela afetividade.

$\mathrm{Na}$ realidade, trata-se de uma questão entre a moral e a afetividade, bem como frisa Piaget, segundo La Taille (1992, p. 47-49) ${ }^{2}$ :

Uma boa maneira de se compreender e avaliar a articulação, feita por um determinado autor, entre afetividade e inteligência é analisar as concepções deste acerca do tema do juízo moral. De fato, a moralidade humana é o palco por excelência onde afetividade e Razão se encontram, via de regra, sob a forma do confronto. [...] Toda moral consiste num sistema de regras e a essência de toda moralidade deve ser procurada no respeito que o indivíduo adquire por estas regras.

\footnotetext{
${ }^{2}$ Ensaio sobre a teoria de Piaget: Desenvolvimento do Juízo Moral e Afetividade.
} 
Assim, a relação entre moralidade e as relações sociais pela afetividade dentro do processo educativo, o respeito entre os seres que compõem o grupo social deve ser imperativo. O que Piaget chama de "jogo de regras", é o cenário onde o desenvolvimento moral da criança se estabelece em suas relações psicossociais. É o que bem retrata, ainda, La Taille (1992, p. 69a) quando discorre sobre a afetividade e inteligência na teoria piagetiana do desenvolvimento do juízo moral:

(...) O sistema democrático pede a cooperação. Basta verificar quais são suas exigências: levar em conta o ponto de vista alheio, respeitá-lo, fazer acordos, negociações, contratos com o outro, admitir e respeitar as diferenças individuais, conviver com a pluralidade de opiniões, de crenças, de credos etc. Além do mais, pelas características do mundo moderno, somos cada vez mais levados a ter de encontrar e nos relacionar com pessoas de culturas diversas, de formação diversa, de religiões diversas. Vem daí que o ideal da "padronização" do comportamento tornase totalmente impossível de ser realizado. Como diz Piaget, a nova exigência é a de coordenar os diversos pontos de vista e diferenças e não mais de reduzi-los através de modelos a serem imitados por todos.

Avaliando o ponto de vista multifacetado das relações sociais, cria-se um padrão de consciência coletiva, estabelecendo-se o respeito mútuo nas interações sociais, onde se cria, igualmente, um senso afetivo individual ${ }^{3}$, o que muito ajuda no sentido educacional. Esse é o ponto crucial em que a evolução da inteligência estrutura o mundo afetivo por meio das questões da moralidade. Porém, a afetividade é que se torna um desafio para o desenvolvimento da inteligência na base das relações sociais, ainda mais em se tratando de educação.

Enquanto Piaget preocupa-se como a afetividade interage com o desenvolvimento por meio das relações sociais movidas pela moral, Vygotsky enaltece a questão cognisciva entre o pensamento e a linguagem, da evolução dos processos psicológicos superiores por meio dos instrumentos e símbolos, como a própria linguagem e as suas representações metacognitivas. Ou seja, o desenvolvimento no processo de ensino-aprendizagem insere-se em três aspectos interdependentes: o cognitivo, o afetivo e o psicológico.

Em suma, Vygotsky, segundo Oliveira (1992, p.75), afirma que houve época em que os aspectos cognitivos e afetivos eram estudados separadamente, sendo hoje uma tendência de reunião entre eles, numa tentativa de recomposição do ser psicológico completo.

Portanto, afeto, educação e relações sociais andam juntos e interligados, cabendo ao mediador preocupar-se sempre com tais aspectos no desenvolvimento da consciência de seus educandos, o que requer uma visão holística dentro do processo educacional.

\footnotetext{
${ }^{3}$ O que Piaget chama de desenvolvimento da moral autônoma.
} 


\section{II - EDUCAÇÃO INCLUSIVA - ALTERIDADE E APRENDIZAGEM DO ALUNO COM TRANSTORNO GLOBAL DO DESENVOLVIMENTO - TGD}

De acordo com a Convenção sobre os Direitos das Pessoas com Deficiência (2006), ratificada pelo governo brasileiro por meio do Decreto Legislativo 186/2008 e do Decreto Executivo 6949/2009, se reconhece o direito das pessoas com deficiência a uma educação de qualidade.

Visando a efetivação deste direito, sem discriminação e sobre a base da igualdade de oportunidades, será assegurado um sistema de educação inclusivo a todos os níveis, assim como o ensino ao longo da vida. Na perspectiva da educação inclusiva, a educação especial passa a integrar a proposta pedagógica da escola regular, promovendo o atendimento às necessidades educacionais específicas de alunos com deficiência, transtornos globais do desenvolvimento e altas habilidades/superdotação.

Em uma escola inclusiva, todos os alunos aprendem juntos, independentemente das suas condições pessoais, sociais ou culturais. Trata-se de construir uma escola na qual não existam "requisitos de entrada", nem mecanismos de seleção ou discriminação de nenhum tipo, uma escola que modifique substancialmente sua estrutura, seu funcionamento e sua proposta pedagógica para responder às necessidades educacionais de todos e de cada um dos alunos. A partir desta perspectiva, cabe à escola adaptar-se aos alunos e não estes a ela.

O processo de inclusão educacional é considerado um tema de ampla complexidade, especialmente no que se refere à questão inclusiva de crianças portadoras de alguma disfunção, como o caso do Transtorno Global de Desenvolvimento. O que torna a proposta deste item um desafio a ser amplamente discutido, o qual de antemão requer fazer uma reflexão sobre pré-requisitos que vão desde a preparação das instituições de ensino em receber esse tipo de clientela, a historicidade do professor, o papel e o contexto familiar, a receptividade por parte dos pares (colegas de turmas), os aspectos históricos até as garantias dos direitos legais, no caso, a legislação que rege o assunto.

Inclusão pressupõe aceitação, mudança de hábitos e de atitudes, autoestima, um mensurador psicológico que carrega estímulos motivados pela afetividade, impulsionando uma criança a ultrapassar seus próprios limites. Fator este que justifica a importância da busca 
incessante por parte dos professores, psicólogos, cientistas, médicos neurológicos e pedagogos, a projetarem suas pesquisas, mesmo que incorram em erros, soluções paliativas, a nunca desistirem da formulação de novas metodologias em função do processo da educação inclusiva

Para ratificar os limites de cada indivíduo, por serem de diferentes naturezas, ideologia própria, concepções de mundo, sentimentos e modos de agir diferentes, vale a pena ainda frisar que:

(...) o desenvolvimento é sempre um pré-requisito para o aprendizado e que, se as funções mentais de uma criança (operações intelectuais) não amadureceram a ponto de ela ser capaz de aprender um assunto particular, então nenhuma instrução se mostrará útil. (VYGOTSKY, 1987 p. 104).

Portanto, a questão do desenvolvimento está atrelada ao fator do conhecimento prévio, o que procede no trato da educação inclusiva. Esse desafio torna-se instigante, quando respeitadas as particularidades de cada indivíduo, seu raciocínio próprio, a maximização de seu potencial; aspectos relevantes que não devem ser negligenciados a nenhuma criança em desenvolvimento.

É um exercício de tolerância e respeito ao próximo, o qual ninguém pode ficar de fora, uma vez que à medida que as ciências vão evoluindo em seus conceitos, evoluem também as políticas sociais, educacionais e legislativas.

Destarte, o sucesso da inclusão educacional começa na fase escolar inicial, num ritmo paulatino, gradativo, onde o papel do professor é extremamente fundamental para a formação psicossocial do aluno.

Para Werneck (1993, p.56): “evoluir é perceber que incluir não é tratar igual, pois, as pessoas são diferentes! Alunos diferentes terão oportunidades diferentes, para que o ensino alcance os mesmos objetivos. Incluir é abandonar estereótipos".

Talvez a falha do sistema educacional esteja na estrutura da composição das classes, deixando a entender, entre linhas conforme Werneck, que o processo educacional deveria ser individualizado. Ou seja, a maior parte do tempo deveria ser dedicada a uma educação particularizada, e outra menor parte deveria ser sociabilizada, compartilhada para que não ocorra um erro histórico e impeditivo para qualquer ser humano, em qualquer área que atue: o preconceito, promovido pela ignorância, a de informação e indiferença social.

Assim sendo, pode-se afirmar que inclusão refere-se ao compartilhamento das diferenças. E que o processo educativo está associado ao processo de sociabilização, porém, a questão de aprendizado relaciona-se com fatores psicológicos e emotivos. Por isso, não há 
como manter uma unanimidade do processo educativo pelas características de pluralidade intelectual.

Portanto, receber um aluno com transtorno, num primeiro momento, torna-se uma tarefa complexa, mas que aos poucos pode ser amenizada, porque com o perpassar dos dias, podem ocorrer uma relativa experiência de aceitação ou de rejeição, dependendo do grau de afetividade, empatia e respeito, dentro do processo de inclusão educativa.

Para Sassaki (1997, p. 41),

inclusão é um processo pelo qual a sociedade se adapta para poder incluir, em seus sistemas sociais gerais, pessoas com necessidades especiais e, simultaneamente, estas se preparam para assumir seus papéis na sociedade.

\subsection{Escola e o Paradoxo: Inclusão x Exclusão Educacional}

A educação inclusiva deve ser entendida como uma interação social e cultural. O verbo incluir assume as acepções de compreender, abranger, conter, inserir, incluir, estar incluído ou compreendido, fazer parte, inserir-se. ${ }^{4}$

Ultimamente, as investigações inerentes aos estudos para compreensão da inclusão educacional, têm cooperado bastante na organização de propostas educativas com o intuito de melhor atender as necessidades das crianças em idade escolar.

A partir do momento que a criança tem a oportunidade de ingressar em uma instituição escolar, ela pode ter contato com outras crianças, conhecer um ambiente diferente do espaço da sua casa, as regras e normas que regem a vida social nesse novo espaço, entre outros fatores. Para isso é importante que as instituições estejam preparadas para recebê-las, preparação que exige adequação desde o ambiente físico-educativo, até a elaboração de propostas de trabalho que contemplem as reais necessidades desses pequenos novos cidadãos, principalmente na forma como o professor vai se relacionar com essas crianças.

Portanto, antes de se falar em educação inclusiva, há que se criar um ambiente propício, preparado para receber a clientela especial, com docentes especializados, capacitados e integrados ao sistema educacional. Pois, como enfatizado na Declaração de Salamanca (UNESCO, 1994) a educação inclusiva é entendida como um processo de inclusão

\footnotetext{
${ }^{4}$ Conforme o dicionário Aurélio.
} 
dos portadores de necessidades educacionais especiais ou de distúrbios de aprendizagem na rede comum de ensino em todos os seus graus.

Em relação a esse tema, Sassaki (1999, p. 167) é bem categórico em afirmar sobre a inclusão social como sendo um processo pelo qual

a sociedade e o portador de deficiência procuram adaptar-se mutuamente tendo em vista a equiparação de oportunidades e, consequentemente, uma sociedade para todos. A equidade social preestabelece a inclusão educacional. [Grifo nosso]

O fato é que o modelo atual de educação está "preparado" para atender alunos dentro dos padrões normais, com capacidade cognisciva esperada para os seus moldes, adaptando-se a programas que combatam a evasão escolar, negligenciando os problemas socioemocionais, psicológicos e comportamentais que muitas vezes os levam ao fracasso escolar.

Torna-se conveniente fazer um aparte sobre a escola pública:

\begin{abstract}
A escola pública, criada a partir dos ideais da Revolução Francesa como veículo de inclusão e ascensão social, vem sendo em nosso país inexoravelmente um espaço de exclusão - não só dos deficientes, mas de todos aqueles que não se enquadram dentro do padrão imaginário do aluno "normal". As classes especiais, por sua vez, se tornaram verdadeiros depósitos de todos aqueles que, por uma razão ou outra, não se enquadram no sistema escolar (GLAT, 2000. pg. 18).
\end{abstract}

Isso leva a crer que velhos paradigmas ideológicos hão de ser quebrados, pois, as ciências sociais evoluem e o comportamento humano evolui igualmente dentro de cada contexto histórico. Assim como as teorias e teses sobre o ideal de cada época, no caso aqui, os moldes da escola pública foram feitos em função dos alunos considerados normais.

Outras desmistificações a serem levadas em consideração, em termos conceituais, referem-se ao campo semântico. Não há como confundir inclusão com integração. Enquanto esta não corresponde ao envolvimento, aquela é extremamente comprometedora. Destarte, o aluno especial não pode ser visto como ajudante, fazer papeis secundários, muito menos antagonistas, são alunos protagonistas inserido numa classe escolar regular e interagindo, compartilhando com os demais colegas de sala, participante de um processo socioeducacional, não podendo ser apenas um número estatístico para justificar projetos políticos mal elaborados, de interesses pessoais e descompromissados com a realidade de fato.

Existem erros de interpretação, a sociedade exclui ao invés de incluir, os programas escolares governamentais encontram soluções coletivas e paliativas, sem discussões acadêmicas e didático-científicas. Os planos já vêm elaborados, de cima para baixo e muitas vezes por parlamentares, com intuitos eleitoreiros, ou por leigos no assunto. Quando deveriam 
sair de centros científicos, acadêmicos e com fundamentação das interdisciplinaridades entre as ciências. Evidências iguais a estas são encontradas nas próprias leis, portarias, normas governamentais, como o caso versando sobre a Política Nacional de Educação Especial:

\footnotetext{
O acesso de alunos com necessidades educacionais especiais no ensino regular é admitido àqueles que: (...) possuem condições de acompanhar as atividades curriculares programadas do ensino comum, no mesmo ritmo que os alunos ditos normais. (MEC/SEESP, 1994: p.19).
}

Fica claro que essa equiparação intelectiva é um erro clássico, uma dissimulação que imbui a ideia de somente aceitarem alunos com características normais e aptos ao ensino.

Esse pensamento começou a ser reinterpretado e a mudar de rumo a partir de 2008 com uma significativa mudança do texto:

[...] Um paradigma educacional fundamentado na concepção de direitos humanos, que conjuga igualdade e diferença com valores indissociáveis, e que avança em relação à ideia de equidade formal ao contextualizar as circunstâncias históricas da produção de exclusão dentro e fora da escola. (MEC/SEESP,2008a).

Em função desse contexto, entende-se que deva haver uma coesão de ações, incluindo órgãos governamentais, escolas públicas, universidades, cientistas, docentes, parlamentares, enfim, todos os sujeitos envolvidos no processo educacional que consigam construir políticas públicas de caráter social, voltados para soluções pedagógicas que incluam a comunidade menos favorecida, aqui no caso, as crianças com algum tipo de transtorno.

\subsection{O TGD e o seu olhar para o mundo}

O Transtorno Global do Desenvolvimento é a nomenclatura utilizada para descrever a patologia que se manifesta através de

$$
\begin{aligned}
& \text { comportamentos característicos de síndromes e quadros psicológicos, neurológicos e } \\
& \text { ou psiquiátricos persistentes que ocasionam atrasos no desenvolvimento e prejuízos } \\
& \text { no relacionamento social, em grau que requeira atendimento educacional } \\
& \text { especializado (Brasil, 1994, MEC - SEESP, p14) }
\end{aligned}
$$

Incluem-se como indivíduos portadores de Transtornos Globais de Desenvolvimento, pessoas com Transtorno Autista, Autismo Atípico, Transtorno de Rett, Transtorno Desintegrado da Infância e Transtorno de Asperger, 
Com base no Manual de Diagnóstico e Estatística das Perturbações Mentais - DSMIV, acerca dos Transtornos Globais do Desenvolvimento, podemos dizer que o aluno com este diagnóstico é aquele que apresenta alterações qualitativas das interações sociais recíprocas e na comunicação, um repertório de interesses e atividades restritas, estereotipadas e repetitivas. Quanto ao tratamento, são usados em alguns casos, medicamentos para tratar problemas comportamentais específicos e ou terapia especializada, de acordo com as necessidades de cada criança. Resalta-se aqui o importante papel de profissionais especializados como fonoaudiólogos, terapeutas, psicólogos, neurologistas e psiquiatras no atendimento e acompanhamento da criança. Atualmente muito tem se investido em pesquisas mas não há cura para os transtornos de espectro autista.

No ambiente escolar, algumas crianças se adaptam bem em classes especiais reduzidas ou mesmo no ensino regular com suporte psicopedagógico e auxílio de um monitor para seu acompanhamento no contexto escolar.

Um dado importante em relação aos TGDs é que existem mais meninos do que meninas, numa proporção de 4 para 1 . Hoje, as pesquisas comprovam que as causas dos quadros de Transtornos de Desenvolvimento Global é multifatorial, dependendo de fatores genéticos e ambientais ${ }^{5}$.

Diante de tantas características específicas em relação a portadores de TGD, a escola tem aqui um grande desafio - atendê-los em sua plenitude e necessidades. Algumas metodologias são pertinentes para o desenvolvimento de habilidades e competências. Uma metodologia bastante utilizada como meio de intervenção comportamental no tratamento dos sintomas é o Applied Behavior Analysis (ABA) ou Análise Aplicada do Comportamento. É uma abordagem da área da psicologia usada para a compreensão do comportamento com objetivo de modificá-lo. Os princípios do ABA respaldam-se no Behaviorismo, que observa e explica a associação entre o ambiente, o comportamento humano e a aprendizagem. A utilização do ABA permitirá que as crianças adquiram competências básicas, ao nível social e cognitivo, e reduzam seus comportamentos estereotipados e destrutivos propiciando serem mais independentes.

Outra alternativa metodológica é o Programa Treatment and Education of Autistic and Related Communication Handicapped Children (Teacch), que em português significa Tratamento e Educação para Autistas e Crianças com Déficit Relacionados com a Comunicação. Trata de um programa educacional e clínico com uma prática

\footnotetext{
${ }^{5}$ Vide: SCHWARTZMAN, José Salomão. Autismo e outros transtorno do espectro autista. In: Revista Autismo. Disponível em: http://revistaautismo.com.br/ Acessado em 24/03/2011.
} 
predominantemente psicopedagógica, fundamentada em pressupostos da teoria comportamental e da psicolingüística. Os princípios metodológicos do Teacch incluem estímulos visuais, os corporais e audiocinestésicos para desenvolver a comunicação. Utilizase de fotos, figuras, cartões gestos, movimentos corporais, som, palavra e movimentos associados às fotos. As atividades que serão desenvolvidas na escola são programadas individualmente e ensinados um a um até que faça parte da rotina da criança de forma sistemática.

O que se observa em crianças diagnosticadas com tal transtorno podem ser abordadas a partir de três áreas distintas: interação social, a comunicação e o aspecto comportamental. A interação social caracterizam os indivíduos com dificuldades ou impossibilidades de estabelecer relações interpessoais significativas com os outros. $\mathrm{Na}$ comunicação, podemos encontar crianças que não falam nada, até outras que conversam bastante. Neste último caso aparece a ecolalia, ou seja, a repetição de que foi dito, tardia ou imediatamente. São capazes ainda de reproduzirem histórias de forma automática e fora do contexto. A repetição e o comportamento estereotipados marcam o comportamento do indivíduo que apresenta esse transtorno. Os TGDs, normalmente preocupam-se com as partes em detrimento do todo a exemplo de fixação por pequenos objetos de certa categoria, como animais, carros, rodinhas, tampinhas os quais se tornam parte do seu ser.

\subsubsection{O papel do outro no processo de aprendizagem do TGD}

Torna-se fundamental então, identificar o papel do outro no processo de aprendizagem da criança com TGD. Este outro entendido aqui, como mediador das relações e do próprio conhecimento. As constantes interações entre as pessoas, a partir de uma relação vincular caracterizam a aprendizagem, pois é através do outro que o indivíduo vivencia e adquiri novas formas de agir e pensar, permeando assim, novos conhecimentos.

Neste sentido, o conceito de zona de desenvolvimento proximal e a mediação compõem o cenário da relevância do outro social tendo em vista o caráter social da aprendizagem, em especial do aluno TGD.

Para tanto, destaca-se o processo de comunicação, que cria indutores, enfatizando a relevância do vínculo afetivo com o objeto de estudo, tendo como critério a comunicação, seja 
por meio da comunicação falada, escrita, auditiva, sensorial, ou até mesmo com troca de olhares estabelecendo um diálogo que possibilite o desenvolvimento cognitivo do aluno, e como tal, contribua no avanço do processo ensino-aprendizagem.

Tais procedimentos há que ser recorrentes na proporção crescente dos contatos, e no intuito de se criar habilidades por meio das experiências cíclicas que fortalecem os vínculos entre os sujeitos do processo de aprendizagem.

Nesse campo, a mediação afetiva traz uma relevante e dinâmica dimensão no desenvolvimento da capacidade humana. Pois, trabalhar o campo afetivo, desperta curiosidades, trabalha com a liberdade de expressão em seu sentido mais estrito, incitam e despertam inquietações perturbadoras em busca de respostas e de soluções.

Blanco (2004) afirma que os professores devem conhecer bem as possibilidades de aprendizagem dos alunos, os fatores que a favorecem e as necessidades mais específicas deles. E que somente com tal conhecimento, poderão ser ajustadas às ajudas pedagógicas ao processo de construção pessoal de cada aluno.

O aluno com alguma necessidade especial, em foco de nosso interesse o TGD, se enquadra perfeitamente a tal conceito, pois, os fatores que os professores devem conhecer, segundo o autor, favorecem as necessidades mais específicas dos alunos. Portanto, o papel do professor, como esse outro social, é substancialmente estratégico e elementar no processo ensino-aprendizagem.

Torna-se um exercício de profunda reflexão que carrega pré-requisitos imprescindíveis os quais abarcam desde a concepção sobre a preparação das instituições de ensino para receber eficazmente seus alunos, passando por uma introspecção sobre a sua própria historicidade como docente, a interação familiar, o convívio com os colegas em sala de aula, a posição do Estado e a legislação, além dos aspectos históricos.

Do ponto de vista socioafetivo, especialmente em crianças TGD, o professor como mediador do processo, cabe-lhe um importante papel nas suas interações interpessoais escolares. Como características individuais, podem ser indutoras ou não, dependendo de seu perfil autoritário ou permissivo, organizado ou desorganizado, sério demais ou brincalhão, etc. Ou seja, são aspectos indutores que podem seduzir ou afastar o aluno, uma questão de empatia, com marcas de personalidade pessoal.

Desta forma, em uma perspectiva dialética, a mediação e a interação social permeiam o papel do outro e garantem espaço diferenciador no processo de aprendizagem possibilitando significação para o aluno TGD e contribuindo assim, com a constituição do sujeito na e pela interação com os outros. 


\section{III - OBJETIVOS}

\subsection{Objetivo Geral}

No objetivo central da presente pesquisa, o intuito é buscar elementos a partir da realidade escolar, que revelem a capacidade e potencial da mediação afetiva, na função de contribuir com o processo de inclusão educacional, compreendendo o papel das relações afetivas no contexto escolar e sua relevância, a meta maior: a inclusão educacional.

E, nesse sentido, tal perspectiva se torna ainda mais imprescindível, quando nos referimos ao processo inclusivo de um TGD, pois sabemos que os indivíduos acometidos de tal transtorno, têm como principal limitação estabelecer diretamente inter-relações com o outro. Por essa razão, o outro (seja professor, aluno, família, escola) pode, se houver intencionalidade pedagógica, agir na promoção dessa interação. Por isso, pretende-se investigar com profundidade até que ponto isso ocorre na realidade pesquisada.

\subsection{Objetivos Específicos}

Para tanto, propomos quatro objetivos específicos com a finalidade de responder ao questionamento que norteia essa pesquisa.

Assim, visa-se identificar a contribuição da mediação afetiva entre professor e aluno no processo de inclusão educativa. Ou seja, perceber qual a qualidade do vínculo estabelecido entre professor-aluno ANEE-TGD, esse vínculo contribui com o processo de aprendizagem desse aluno. Ou ainda, existe algum vínculo afetivo, ou apenas a relação professor (profissional) - aluno (clientela), como uma relação de cumprir com "obrigações".

Para isso, faz-se necessário uma análise do contexto social em que se insere o aluno TGD, no intuito de averiguar até que ponto a interação pode interferir no comportamento do aluno e seus pares. Analisando o desenvolvimento da linguagem e a progressiva ou não evolução do aluno, objeto da pesquisa, dentro desse processo. 
Tentando conhecer a realidade vivencial do aluno e sua real limitação propôs-se verificar até que ponto as limitações específicas do aluno diagnosticado com TGD atrapalham as trocas afetivas entre o aluno e seu ambiente. Observar se há uma evolução cognitiva por meio das trocas afetivas, buscando respostas às suas limitações.

E, para entender o papel do professor no processo de inclusão educacional, objetivouse identificar qual a mediação pedagógica o docente utiliza para possibilitar a interação deste aluno com o ambiente e o outro propiciando meios mediacionais do ponto de vista do docente, entrelaçando conceitos e metodologias que possam contribuir na interação entre seus pares e o aluno. 


\section{IV-METODOLOGIA}

\subsection{Pressupostos teóricos}

A construção do processo metodológico para a contribuição do estudo da inclusão, no caso Transtorno Global do Desenvolvimento - TGD dentro da relação afetiva aluno-professor, torna-se uma tarefa árdua, para atingir resultados efetivos; uma vez que quando se fala em equidade educacional, especialmente neste caso, esbarra-se em dois pontos de vista distintos, porém, paradoxalmente interdependentes: o social e o psicológico.

Entretanto, a relação ensino-aprendizagem trabalha exatamente com estes dois pontos, onde a construção do conhecimento em função da inclusão cristaliza-se em batalhas dentro da visão pedagógica. Um processo dialético, onde o docente cria projetos, levando em consideração a sua historicidade, formação e capacidade educacional.

Sendo assim, o cerne metodológico deste trabalho é exatamente encontrar um catalisador que mensure por meio da mediação afetiva o processo inclusivo educacional, observando-se os aspectos socioculturais e psicológicos, especificamente, dentro da visão de um estudo de caso de um aluno com Transtorno Global do Desenvolvimento, a relação afetiva entre professor e aluno, partindo-se da preocupação sobre até que ponto esta troca de afetividade contribui ou não para o processo de inclusão educacional deste aluno dentro de seu contexto escolar.

Por essa ótica, nesta pesquisa, será utilizada a investigação qualitativa, que segundo Branco; Valsiner (1997, 1999); González-Rey(1997,1999) possui um caráter essencialmente teórico, utilizando-se de estudo de caso que tem como objetivo retratar de forma completa e profunda a realidade enfatizando a complexidade da situação procurando revelar a multiplicidade de fatos que envolvem e a determinam.

O foco de interesse na pesquisa qualitativa é amplo e dela faz parte a intenção de obtenção de dados descritivos mediante contato direto e interativo do pesquisador com a situação objeto de estudo para entender os fenômenos segundo a perspectiva dos participantes da situação estudada e, a partir dos dados, situar as interpretações dos fenômenos, considerando o contexto histórico estudado.

O estudo de caso é um dos tipos de pesquisa qualitativa, em específico, trata-se de 
(...) uma categoria de pesquisa cujo objeto é uma unidade que se analisa profundamente. Pode ser caracterizado como um estudo de uma entidade bem definida, como um programa, uma instituição, um sistema educativo, uma pessoa ou uma unidade social. Visa conhecer o seu "como" e os seus "porquês", evidenciando a sua unidade e identidade própria. É uma investigação que se assume como particularística, debruçando-se sobre uma situação específica, procurando descobrir o que há nela de mais essencial e característico ${ }^{6}$.

E, nesse caso, como a realidade a ser pesquisada refere-se ao contexto escolar de um aluno TGD, tal método atende ao propósito da pesquisa em questão. Tentando, assim, apreender várias fontes de informação, recorreremos a uma variedade de dados coletados em diferentes momentos, em situações e informantes variados. Portanto, este capítulo destina-se a especificação sobre o método de procedimentos e análises para gerar resultados visando a coleta de dados a partir das experiências vivenciadas na sala de aula com aluno TGD, no material didático oferecido, na estrutura física em que a escola se apresenta e, essencialmente, nas possíveis interações deste com os outros e vice-versa.

\subsection{Contexto da pesquisa}

A realidade contextual do ambiente escolar público no país, no caso aqui nas escolas públicas do Distrito Federal, em última análise, é precário em termos de estruturas e infraestruturas, o que não é diferente no colégio em que estuda a aluna Aline ${ }^{7}$ - nosso sujeito de pesquisa-estudo. $\mathrm{O}$ grande questionamento que se faz é o seguinte: será que o ambiente escolar está preparado para receber criança portadora de TGD?

No atual capítulo será abordado o contexto in locus onde será desenvolvida a pesquisa, e será especulado o plano geral, incluindo-se os instrumentos empregados no intuito da escolha dos sujeitos participantes, objetivando a construção dos dados, os perfis e relações sociais dos participantes, bem como dos procedimentos para análise dos dados.

O estabelecimento de ensino, escola padrão de ensino público da Secretaria de Estado de Educação do Governo do Distrito Federal está localizado na cidade-satélite do Guará. Trata-se de uma escola antiga, a primeira escola construída para atender a população dessa região. Essa Escola Classe existe há 42 anos, sendo inaugurada em 1969, um lugar agradável,

\footnotetext{
${ }^{6}$ MARTINS, M.A.H. Estudo de caso. Disponível em <http://mariaalicehof5.vilabol.uol.com.br/> Acesso em 29/03/2011.

${ }^{7}$ Nome fictício para preservar a identidade da menor
} 
aparentemente tranquila na qual frequenta alunos com perfil de classe média, porém, nota-se uma certa diversidade econômica, pois, além de atenderem alunos da cidade local, atende igualmente os de lugares economicamente menos favorecidos.

Suas dimensões medem $3.200 \mathrm{~m}^{2}$ de área total e 1.851,66 de área construída, possuindo estacionamento externo para o corpo docente e pais de alunos, um pequeno parquinho de areia e pátio interno para recreio e desenvolvimento de atividades recreativas.

Em termos de infraestrutura possui: dois bebedouros de parede no pátio, filtros em cada sala de aula e sistema de som espalhados pela escola, é composta de 07 salas de aula, uma sala para os docentes e coordenação pedagógica, cantina, Sala de Leitura, Laboratório de Informática, Direção, Secretaria, 02 banheiros para os alunos adaptados para atendimento à Educação Infantil, 02 para atender alunos do Ensino Fundamental, 02 banheiros para os professores e uma pequena horta onde é desenvolvido o Projeto Horta pela professora do Atendimento Especializado - Sala de Recursos.

A escola atende alunos da Educação Infantil e Ensino Fundamental até o quinto ano, constando o número de 302 alunos, distribuídos em 141 no turno matutino e 161 no turno vespertino. O corpo docente é formado por 22 professores, 01 Orientador Educacional, 01 diretor, 01 vice-diretor, 01 Supervisor Pedagógico, 01 auxiliar administrativo, 01 secretário, 02 auxiliares de secretaria, 04 porteiros, 02 merendeiras, 06 profissionais de serviços gerais de limpeza e 04 vigias noturno.

A sala dos professores é pequena, encontra-se equipada, com armários individuais, mesa redonda com cadeiras para reuniões e coordenação pedagógica, sofás, murais, e 01 computador de uso coletivo além de materiais didático-pedagógicos.

A sala de aula da turma, onde fora realizada a pesquisa, além das carteiras, havia mobiliário padrão das escolas públicas, armário para professor, quadro branco, carteira, murais, 02 ventiladores, em um dos cantos da sala um baú com brinquedos e uma caixa com livros infantis.

\subsection{Participantes}

Para a pesquisa em questão, são participantes os seguintes indivíduos:

a) Aline é filha única, vive sob a guarda da avó, mas os pais participam de sua educação. Aluna regularmente matriculada e freqüente na escola desde 
agosto de 2008. Proveniente de escola particular a família relata que não percebia qualquer avanço na criança. Então decidiu-se juntamente com os profissionais que a atendem que era necessário inserir- lá no sistema público de ensino, pois segundo a mãe seriam capazes de atendê-la melhor. Nasceu de parto prematuro, com hemorragia intracerebral, evoluindo para hidrocefalia. De acordo com o médico neurologista que a acompanha, apresenta seqüelas neuronais que acarretaram em déficit motor e psíquico CID F84. 1(Autismo Atípico), F81.8(Outros Transtornos do Desenvolvimento das Habilidades Escolares), F80(Transtorno Específico da Articulação da Fala), F82(Transtorno Específico do Desenvolvimento Motor), F83(Transtornos Específicos Misto do Desenvolvimento), I60.0(Hemorragia Subaracnóide proveniente do Sifão e da Bifurcação da Carótida), F71(Retardo Mental Moderado) e G91(hidrocefalia) ${ }^{8}$. Aline é acompanhada por psicólogo, psiquiatra, psicomotricista e fonoaudiólogo em clínica particular em horário contrário ao das atividades escolares. O atendimento é realizado três vezes por semana.

b) Professora Regente - A professora que atende a aluna em sala regular tem 22 anos de experiência no ambiente escolar e ainda em coordenação pedagógica. Licenciada em pedagogia com pós-graduação lato sensu em Psicopedagogia. Porém foi seu primeiro ano de contato direto com aluno com necessidades educacionais especiais.

c) Professora da Equipe de Atendimento Educacional Especializado (Sala de Recursos) - A professora da Sala de Recursos conta com 24 anos de experiência em educação e há quatro anos atende em sala especializada alunos com necessidades educacionais especiais. Possui formação em Pedagogia, Geografia e pós-graduação em Psicopedagogia.

d) Supervisora Pedagógica - Profissional formada em Pedagogia- Séries Iniciais com especialização em Psicopedagogia, com 17 anos de Secretaria de Educação, tendo passado por várias experiências dentro do ambiente escolar - direção, sala de aula, professora de informática e coordenação pedagógica.

\footnotetext{
${ }^{8}$ Classificação Estatística Internacional De Doenças E Problemas Relacionados À Saúde - CID -10. Disponível em: http://www.datasus.gov.br/cid10/v2008/cid10.htm. Acesso em 25/03/2011.
} 
e) Pesquisadora - Integra o quadro de Especialista de Educação Orientadora Educacional da Secretaria de Estado de Educação do Distrito Federal há 13 anos e atua nesta instituição de ensino há 4 anos. Participa ativamente no processo de inclusão de alunos especiais e desenvolve projetos em parceria com a coordenação pedagógica, professores e direção auxiliando na sensibilização da comunidade escolar para a educação inclusiva, favorecendo a sua implementação no contexto educativo.

\subsection{Materiais}

Os recursos materiais empregados na composição, organização e análise das informações foram os seguintes: gravador, roteiro de entrevista, diário de campo, papel sulfite, lápis de cor, brinquedos pedagógicos. No que se refere à sistematização, registro e formatação do trabalho escrito: computador, internet, caneta esferográfica, papel, livros, material impresso e da web.

\subsection{Instrumentos de construção de dados}

Os instrumentos empregados na estruturação do levantamento das informações foram os seguintes: a observação, diário de campo, entrevista semi-estruturada com a professora regente da aluna, com a professora da Sala de Recursos e a Supervisora Pedagógica e análise documental.

\subsubsection{A Observação}

A observação é uma técnica de coleta de dados, que não consiste em apenas ver ou ouvir, mas também em examinar fatos ou fenômenos que se desejam estudar. É um elemento básico de investigação científica, utilizado na pesquisa de campo como abordagem qualitativa. Para a observação foi utilizado um roteiro de observação, elaborado a partir dos objetivos desta pesquisa para o amplo e detalhado estudo da situação e contexto pesquisado. 


\subsubsection{Diário de campo}

O diário de campo serve de instrumento técnico utilizado no registro das inserções ao campo e são construídos evidenciando os acontecimentos, observações e questionamentos do pesquisador. As anotações no diário de campo indicam questões que devem ser aprofundadas na busca da compreensão do fenômeno estudado e para a reflexão crítica da pesquisa.

\subsubsection{Entrevista semi-estruturada}

A entrevista tem o objetivo de obter informações sobre o objeto de estudo, averiguar fatos, opiniões e sentimentos. Para Triviños (1987, p. 146) a entrevista semi-estruturada tem como característica questionamentos básicos que são apoiados em teorias e hipóteses que se relacionam ao tema da pesquisa. Para Manzini (1990/1991, p. 154), a entrevista semiestruturada está focalizada em um assunto sobre o qual confeccionamos um roteiro com perguntas principais, complementadas por outras questões inerentes às circunstâncias momentâneas à entrevista. Para o autor, esse tipo de entrevista pode fazer emergir informações de forma mais livre e as respostas não estão condicionadas a uma padronização de alternativas.

Para tanto, foi elaborado um roteiro, com o objetivo de nortear a entrevista para atender pais e professores. Os roteiros não são fixos, apenas servem como norteadores, o que não impossibilita considerar outros aspectos de relevância à pesquisa que emergem no processo de diálogo, que, não foram considerados anteriormente, como pressupõe a dialética das relações.

\subsubsection{Análise documental}

Com a análise de documentos objetiva-se o recolhimento e levantamento de dados a cerca da especificidade do diagnóstico da aluna, histórico escolar e proposta de adaptação curricular. 


\subsection{Procedimentos de construção de dados}

Após a referida proposta ter sido aprovada pela orientadora do curso de Especialização em Desenvolvimento Humano, Educação e Inclusão, da UAB/UNB, realizou-se o trabalho de campo. Foram providenciados os procedimentos legais em relação ao Termo de Consentimento Livre e Esclarecido (TCLE), (Anexo A) devidamente assinado pelo responsável do aluno (pais) participante, bem como, foram tomadas as devidas providências em relação ao direito da individualidade e imagem dos participantes, resguardando ao aluno participante total sigilo em relação às informações coletadas ao seu respeito: nomes, detalhes particulares, etc.

O critério de escolha da Instituição de Ensino se deu devido ao prévio conhecimento que tinha da escola e por saber que esta atendia a uma aluna diagnosticada com transtorno global de desenvolvimento. A escolha do objeto de estudo ocorreu por ter acompanhado o processo de inclusão da aluna através de relato de professores daquela instituição.

Assim, o estudo constituiu-se de quatro estágios: estágio A: seleção do aluno participante, estágio B: entrevistas, estágio C: observações da rotina na escola do objeto de estudo e estágio D: análise documental.

O primeiro contato foi feito com a Diretora e a Supervisora Pedagógica daquele estabelecimento. Após explanar a proposta do projeto de pesquisa com extensa e criteriosa conversa e análise sobre o objeto de estudo foi entregue uma cópia do projeto à escola. Esclarecendo o propósito da escolha da referida instituição que fora feito por indicação de um colega que também é funcionário da Rede de Ensino, logo se instaurou uma cordialidade mútua, o que facilitou bastante o trabalho do pesquisador.

Daí, depois de explicitado o objetivo da pesquisa à direção da escola, buscou-se contato direto com a professora regente da aluna e após apresentar o projeto, informei-lhe do critério de seleção do sujeito a ser pesquisado: criança com TGD.

Então, ficou acordado que o pesquisador iniciaria suas observações.

\subsubsection{Observação}

A observação foi sistematicamente planejada e registrada de forma descritiva, objetivando perceber as vozes do sujeito, a reconstrução de diálogos, descrição de locais, atividades e 
comportamentos. Para melhor visualização a tabela abaixo apresenta alguns dados dessas observações:

Tabela 1 Dados da observação

\begin{tabular}{|c|c|c|c|}
\hline Sessão & Data & Objetivo & Produto \\
\hline $\begin{array}{l}\text { Observação } \\
1 \\
\text { Sala de aula }\end{array}$ & 23.11 .2010 & $\begin{array}{l}\text { Interação em sala de } \\
\text { aula }\end{array}$ & $\begin{array}{l}\text { Não houve interação com outros alunos. Realizava } \\
\text { atividade sozinha com o auxílio da monitora. } \\
\text { Apresentou dificuldades no recorte com tesoura. }\end{array}$ \\
\hline $\begin{array}{l}\text { Observação } \\
2 \\
\text { Sala de } \\
\text { Recursos }\end{array}$ & 23.11 .2010 & $\begin{array}{l}\text { Atendimento em Sala } \\
\text { de Recursos }\end{array}$ & $\begin{array}{l}\text { Não se interessou pela atividade com letras. Mostrou- } \\
\text { se motivar para ouvir e contar histórias e realizar } \\
\text { atividade pedagógica no computador. Não respondia às } \\
\text { perguntas da professora, mas entendia exatamente o } \\
\text { que era pedido a cada comando dado na tela. }\end{array}$ \\
\hline $\begin{array}{l}\text { Observação } \\
\quad 3 \\
\text { Sala de aula }\end{array}$ & 25.11 .2010 & $\begin{array}{l}\text { Observar a interação } \\
\text { com os pares e a } \\
\text { professora }\end{array}$ & $\begin{array}{l}\text { Brinca com colegas, mas sua interação é restrita. Não } \\
\text { responde às perguntas do colega, porém entende a } \\
\text { brincadeira. Aline é completamente respeitada em sua } \\
\text { individualidade pelo seu colega. }\end{array}$ \\
\hline $\begin{array}{l}\text { Observação } \\
4 \\
\text { Sala de } \\
\text { Orientação } \\
\text { Educacional }\end{array}$ & 02.12 .2010 & $\begin{array}{l}\text { Identificar meios } \\
\text { mediacionais de } \\
\text { aprendizagem. }\end{array}$ & $\begin{array}{l}\text { Emite sons e frases aparentemente desconexas. } \\
\text { Demonstra confiança na presença da Professora da } \\
\text { Sala de Recursos. Reproduz algumas falas das } \\
\text { personagens de histórias infantis. Constantemente } \\
\text { segura um objeto e o movimenta nas mãos. }\end{array}$ \\
\hline $\begin{array}{l}\text { Observação } \\
5 \\
\text { Recreio }\end{array}$ & 03.12 .2010 & $\begin{array}{l}\text { Identificar o papel do } \\
\text { outro social na } \\
\text { interação com a aluna }\end{array}$ & $\begin{array}{l}\text { Demonstra desejo em participar de brincadeiras, } \\
\text { procura a presença da professora. Não responde aos } \\
\text { cumprimentos dos colegas apenas repete o que ouve. }\end{array}$ \\
\hline
\end{tabular}

\subsubsection{Análise documental}

Os documentos analisados constam do dossiê da aluna do Serviço de Orientação Educacional, dos registros dos atendimentos em Sala de Recursos e da pasta da aluna na Secretaria da escola e foram prontamente disponibilizados, resguardada a privacidade e sigilo das informações. A análise documental se deu em Relatórios de Acompanhamento da aluna, Relatórios Escolares de anos anteriores, diagnósticos e históricos médicos, Ficha de Registro da Adequação Curricular, Avaliações do Desenvolvimento, Relatório Médico e atividades escolares realizadas pela aluna. $\mathrm{O}$ enfoque da análise foi conhecer o percurso da aluna na 
escola e seu histórico médico para melhor compreensão das possíveis limitações e, assim como, suas potencialidades.

\subsubsection{Entrevista}

As entrevistas foram previamente agendadas com as professoras que se mostraram abertas e acessíveis para o relato de suas percepções sobre a aluna. Acredito que meu vínculo com a instituição possibilitou um clima de confiança e descontração na realização da entrevista.

\subsection{Procedimento de análise de dados}

Após a coleta de dados, foi utilizada a técnica de interpretação do pesquisador como indicador que se traduz no desenvolvimento de conceitos e novas categorias no processo da investigação, ou seja, o momento da criação que para Gonzáles-Rey $(1997$; 199; 2005) tais categorias representam um momento da construção teórica de um fenômeno e através dela entramos em novas zonas de sentido, que conduzirão a novas categorias que se integrarão à anterior até chegar ao nível do empirismo.

Para tanto, com base no que se objetivava em cada uma das metas específicas dessa investigação, para melhor visualizar os resultados pretendidos, foram construídas as seguintes categorias de análise com base nos objetivos específicos desse trabalho:

- Mediação afetiva;

- Interação social do objeto;

- Limitações específicas

- Participação do outro no processo de inclusão.

Tais eixos nortearão a organização da discussão dos dados obtidos por meio de cada um dos instrumentos utilizados. 


\section{V- RESULTADOS}

Seguem alguns dados relevantes obtidos com a pesquisa a serem analisados a partir do referencial teórico do trabalho e do contexto atual em que se inscreve a educação inclusiva. Os dados estão organizados por procedimentos de pesquisa aplicados e conforme resultados obtidos à luz dos eixos norteadores mencionados no item 4.7 da Metodologia

\subsection{Entrevistas}

\subsubsection{Mediação afetiva}

\subsubsection{Professora Regente}

Em relação à mediação afetiva ela coloca que a princípio sentiu medo e angústia por não saber qual realidade enfrentaria. Mas com o passar dos dias foi acalmando-se e entendendo que seria "um dia de cada vez". A aluna é bastante carinhosa e me cativou com seu olhar terno e humilde, diz a professora.

\subsubsection{Professora do Atendimento Educacional Especializado}

Comenta que sua relação com a aluna é de troca e de total interação. "Sinto prazer, é uma situação extremamente gratificante estar com a Aline”. Acontece em momentos informais, sempre que aparece oportunidade: eventos, recreio, parque etc. A aluna é incentivada a interagir afetivamente com os colegas através de abraços, passeios de mãos dadas, agradecimentos, e beijos. Com a repetição destes comportamentos e incentivos, espera-se que a aluna interaja e crie vínculos de amizade.

\subsubsection{Supervisora Pedagógica}

A Supervisora acompanhou todo o processo de inclusão da aluna desde o início e considera que foi bastante difícil no início, pois nem a escola e aluna estavam preparadas. Ressalta que foi um choque quando da sua entrada na escola no meio do ano letivo, pois a 
turma em que a aluna foi matriculada estava em pleno desenvolvimento. "No início, eu achei difícil. Apesar de ela ser uma criança maravilhosa, no início foi difícil”. (Supervisora Pedagógica). A professora ressalta que o marcante neste processo de inclusão foi a recepção da aluna pela escola que acolheu e a excelentes professoras que teve durante este três anos nesta instituição.

Em relação à afetividade e o processo de inclusão a supervisora falou da necessidade de preparo para o recebimento destes alunos e da postura do profissional, com isso destaca em sua fala a gritante diferença que observou no comportamento da Aline quando da sua entrada na escola e hoje, completamente adaptada, incluída, respeitada e amada por todos. "Realmente houve um crescimento muito grande da Aline, uma menina que chegou por último na sala. Você vê a diferença marcante". (Supervisora Pedagógica). Ela relaciona a postura dos profissionais que atenderam a aluna em seu processo inicial de inclusão e destaca que o professor deve primar por uma mediação afetiva no que diz respeito ao vínculo, um olhar diferenciado, uma postura afetiva que permita que este aluno se desenvolva.

A instituição física não está preparada para a inclusão, pois, segundo a supervisora, a escola não possui banheiros adaptados, um espaço de recreação adequado, um parque com dimensões que abriguem todos os alunos, sala de brincadeiras ou ludoteca. Ainda falta muito para que esta escola seja ideal para a inclusão.

\subsubsection{Interação da aluna Aline}

\subsubsection{Professora Regente}

Quanto à interação da aluna, a professora comenta que aprendeu bastante com ela e o mais positivo dessa interação foi perceber que temos que entender que todos somos seres humanos. Ela diz que aprendeu bastante com seus outros alunos e suas relações com a aluna, pois eles entendiam perfeitamente qual era a dificuldade da aluna e a respeitavam e para eles isso era normal. "Porque não precisava de nada, nada de especial para que a Aline estivesse dentro da sala junto com eles.” (Professora Regente)

Em relação à interação da aluna TGD no ambiente escolar, a professora conta que não enfrentou dificuldades, mas aprendeu com seus alunos que Aline deveria ser tratada como os outros alunos com as mesmas oportunidades. "Os alunos mantinham um carinho especial pela Aline e sempre estavam prontos para atendê-la e compreendê-la”. Segundo a professora o que no início dificultou foi a heterogeneidade, tanto de comportamento, quanto de 
conhecimento, da turma: "Tinha que preparar quatro planejamentos diferentes para atender as diferenças individuais."(Professora Regente).

\title{
5.1.2.2 Professora do Atendimento Educacional Especializado
}

Segundo a professora, apesar de raros, há momentos em que ela interage espontaneamente com os colegas e até os responde quando é questionada. Conta-lhes histórias e canta junto com alunos, às vezes, até fragmentando a música. Já consegue manifestar o não querer envolver-se em alguma situação, se defende e diz o que não quer, deixando claro sua vontade com muita educação.

\begin{abstract}
"Olha, eu percebi que ela mudou quando se relaciona com a J. Ela aprendeu a se defender da J... que tomava tudo da mão da Aline. Então ela olhava pra mim e eu intervia para resolver a situação. Houve uma situação que a J. sentiu um pouquinho de medo da Aline porque ela começou a tomar as coisas da J. Ela está mais segura quanto a isso... De primeiro ela não falava nada, depois ela começou a chorar, reclamar e gritar. E depois, agora, ela se defende. Ela se defende na mesma hora". (Professora da Sala do Atendimento Educacional Especializado - Sala de Recursos).
\end{abstract}

\subsubsection{Supervisora Pedagógica}

A Supervisora relata que Aline interage com os alunos, porém da sua maneira. "Ela chega, fica perto..."

\subsubsection{Limitações específicas da aluna Aline}

\subsubsection{Professora Regente}

As limitações específicas da aluna levaram à necessidade de realizar a Adequação Curricular quanto à temporalidade, (a aluna tinha um horário especial três horas diárias) em virtude de outros atendimentos que faziam fora da escola o que a deixava cansada. A aluna era acompanhada pela especialista da Sala de Recursos, pela Orientadora Educacional da Instituição e ainda por uma monitora. Este atendimento era sistemático e bastante organizado com horários e atividades pertinentes ao desenvolvimento da aluna. Dentro de sala de aula o apoio da monitora torna-se essencial, pois segundo a professora a aluna mantinha uma rotina:

“(...) Ela tinha uma rotina, ela chegava aqui, guardava o material dela, sentava comigo, fazia as atividades, ouvia música. Sempre tinha alguma coisa que eu planejava que ela tinha que fazer." 
A professora relata ainda, que procurou qualificação e interessou-se em um curso ministrado pela Escola de Aperfeiçoamento de Professores da Secretaria de Educação do Distrito Federal, mas não conseguiu vaga. Então se predispôs a ser ouvinte no curso, mas não foi aceita e comenta que sequer foi permitida sua entrada em sala sendo informada ainda que não iria conseguir a vaga nem como ouvinte. Assim ela comenta:

"Nem como ouvinte, nem tentasse. Foi exatamente o que ela falou para mim. Eu peguei as minhas coisas e fui embora. E a partir desse momento fui trabalhar sozinha. Eu trabalhei sozinha. Passei 365 dias trabalhando sozinha (...)"(Grifo nosso)

\subsubsection{Professora do Atendimento Educacional Especializado}

Ainda são muitas suas limitações, embora já tenha se desenvolvido em vários aspectos. Ela ainda não escreve espontaneamente, necessitando seguir modelos e ter mediação. "Necessita de ajuda para calçar, vestir, escrever, atar e desatar" (Professora da AEE). Usa sozinha e adequadamente o banheiro, alimenta-se, pega e guarda objetos e materiais, encaminha-se para sala sozinha e apresenta certa dificuldade para recortar, colar e saltar.

A professora trabalha com a metodologia ABA E TEACH e enfatiza que a flexibilidade de seu planejamento é o ponto alto de seu trabalho pedagógico. “... às vezes tenho que ter um plano A e até um plano B como estratégias para atingir meus objetivos com a ela”. Considera que o local da sala de aula é bastante barulhento e que não dispõe de materiais pedagógicos suficientes e ou adequados para o trabalho pedagógico com o aluno com transtorno global de desenvolvimento.

\subsubsection{Supervisora Pedagógica}

“ Como ela evolui, do início do ano e até se analisarmos desde sua entrada na escola. Seu crescimento é enorme”(Supervisora Pedagógica). Porém, ela coloca que ainda percebe algumas limitações motoras e no próprio relacionamento dela com os colegas.

5.1.4 A participação do outro no processo de inclusão

\subsubsection{Professora Regente}


As trocas afetivas ficaram explícitas na fala da professora quando ressalta o carinho entre os alunos e a Aline. Segundo a regente,

\begin{abstract}
"Percebia que a minha maior dificuldade foi trazer a (...) para a gente. Porque ela vive no mundo dela. Então a minha maior dificuldade era a falta de entrosamento, porque ela não conseguia um raro entrosamento(...). Os meninos normais, eles têm a (...) como uma aluna dentro da sala, mas, a (...) não. A (...)vive realmente no mundo dela. Raro são os momentos em que ela se abria e deixava com que os meninos entrassem." (Grifo nosso)
\end{abstract}

A professora enfatiza que a aluna age com o coração e os alunos retribuem todo este carinho sendo carinhosos com ela também. Como fica registrado na seguinte afirmação da regente:

\footnotetext{
"Eu vejo como eles são autênticos, eles agem com o que eles acham o que é certo. Então, na minha maneira de ver, eu acho que eles aceitam a (...) do jeitinho que ela é. Todo amor e carinho são o que eles têm, é tudo por conta dela(...). É o que eu vejo amor, carinho e respeito(...). Entendem exatamente o que é que ela é(...). Então é isso o que eu vejo a questão da afetividade em relação a ela. Diferente do adulto, o adulto já tem preconceito. A (...) é bastante querida por toda escola e respeitada em todos seus momentos." (Grifo nosso).
}

A professora comenta que seus alunos não se dispersam em sala de aula com a presença da Aline, mas que o contrário às vezes acontece, pois aluna se irrita bastante com barulho e por ser uma turma com alguns alunos com dificuldades comportamentais e até agressividade isso a perturba e ela se mostra impaciente ou querer sair da sala. A professora relata ainda que agora no final do ano percebe-se um aspecto bem positivo no comportamento da aluna: "ela consegue entender e obedecer aos comandos de ordem e também já se reconhece como pessoa inclusive utilizando-se da primeira pessoal para se referir a ela.". Ela ressalta ainda que o reconhecimento da família da aluna foi muito gratificante quando a avó materna externou o quanto era visível o desenvolvimento da aluna durante o ano letivo de 2010.

Outro dado importante é o fato mencionado pela professora de que todo conhecimento que obteve foi em função de pesquisas na internet, leitura de livros e ainda a falta de materiais pedagógicos específicos para trabalhar com a aluna: "tudo que dispunha em sala de aula adquiri com recursos próprios, como jogos infantis adequados ao caso, materiais de uso coletivo, estantes, mobiliário adequado". A professora comenta que a monitora que a acompanhava em alguns momentos durante a aula não conseguia trabalhar satisfatoriamente com a Aline o que dificultou muito seu trabalho, pois por vezes teria ela própria que 
desenvolver uma atividade com a aluna porque a monitora não conseguia prender a atenção da Aline. Porém, contava também em alguns dias com uma estagiária que conseguia desenvolver atividades pedagógicas específicas com a Aline. Quando perguntada se havia alguma relação dessa situação com a relação afetiva entre a aluna a professora coloca que acredita que não, a questão é mesmo didática de postura pedagógica frente à Aline.

\subsubsection{Professora do Atendimento Educacional Especializado}

Percebe-se na fala da professora que o outro ajuda tentando trazê-la para o mundo real, com atenção, conversas, incentivos, carinho, dando chance de interagir e mostrar-lhe seu talento, para música, números. Vendo-a com olhar de quem pode acrescentar muito a percebendo como uma pessoa "normal" sem enxergá-la com pena e incapacidade.

Segundo ela a interação acontece de maneira natural e espontânea o que contribui muito com o trabalho pedagógico com a Aline. Esta relação propõe uma ajuda no crescimento e possibilita segurança para ela dentro do ambiente escolar. A professora diz perceber isso quando é solicitada pela aluna, com um olhar, ou um pegar na mão. Percebeu que ela aprendeu a se defender de outra aluna com diagnóstico diferenciado que tomava seu objeto e até mesmo a agredia para tomá-lo.

“Ela sempre me procura (...) Ela me procura em situações difíceis, em se
tratando de conflito, e até mesmo ela olha pra mim a procura de aprovação
daquilo que está fazendo(...) e muitas vezes ela nem está comigo, mas pára e
me olha esperando que eu diga alguma coisa ou apenas diga Ah! Que
lindo(...) e depois ela continua o que estava fazendo" (Professora do AEE).

Em relação à interação com outros alunos a professora considera que acontece uma boa interação. Ela conversa, solicita e até aceita contato, canta em coro. Ressalta que houve grande avanço nesta interação durante o ano.

"A relação deles com ela é a melhor possível... eles têm uma... como é que fala... não é só respeito, é um gostar, um cuidado, um prazer de ficar com ela. Tem até briga pra ficar com ela. Uma coisa prazerosa e de cuidado... Agora dela para eles, assim, dentro das possibilidades, existe interação, mas às vezes ela não retribui”. (Grifo nosso). 


\subsubsection{Supervisora Pedagógica}

Na entrevista com a Supervisora Pedagógica fica claro que sua visão acerca da participação do outro no processo de inclusão fez toda a diferença uma vez que ressalta a relação afetiva e sua interação com o outro como propulsora da eficácia desta inclusão. “... Tem que ter um vínculo, procurar ter este vínculo, um olhar diferenciado também... Você acaba vendo aquela pessoa que ela precisa de um atendimento ali... Com direitos iguais”. (Supervisora Pedagógica).

\subsection{Observações}

\subsubsection{Mediação afetiva}

Observou-se em relação à mediação afetiva que Aline pouco ou raramente procura seus pares. No entanto está sempre rodeada pelos colegas que procuram ajudá-la ou simplesmente ficar junto a ela. Seus colegas de sala de aula parecem nutrir um carinho especial por ela e a respeitam da maneira que ela se apresenta, pois não a cobra comportamentos ou reciprocidade. Eles apenas a respeitam.

\subsubsection{Interação da aluna Aline}

Participa do momento do recreio junto com os outros alunos. Porém, sempre é acompanhada pela monitora ou pela Professora da Sala de Recursos e parece ter grande segurança em relação a elas.

\subsubsection{Limitações específicas da aluna Aline}

Aline apresenta comportamentos estereotipados com certa fixação a objetos. Tem sempre nas mãos um objeto, geralmente um animal, e o movimenta entre os dedos em contínuo e cadenciado movimento. Apresenta dificuldades para deslocar-se. Sempre anda como se saltitasse levemente. Demonstra pouco interesse na realização das atividades propostas exceto quando se trata de atividades no computador. 
5.2.4 A participação do outro no processo de inclusão

Quanto à participação do outro no processo de inclusão, observou-se que o outro qualifica a relação com Aline baseada no respeito frente às limitações de interação da aluna. Aline é conhecida por todos os alunos e profissionais que ali atuam. É respeitada em seu silêncio ou num simples "oi" com o olhar vago e distante. Raramente observou-se a aluna sozinha ou preferindo o isolamento. Estava sempre rodeada por colegas ou profissionais que a estimulam constantemente sua linguagem oral e convivência. 


\section{VI - DISCUSSÃO TEÓRICA DOS RESULTADOS}

\subsection{Mediação afetiva}

A partir da apresentação dos dados pode-se identificar que a mediação afetiva contribui com o processo de inclusão do TGD pelo fato de que a evolução do objeto de estudo pode ser considerada como satisfatória. No caso específico da Aline, na fase inicial de seu processo de inclusão, não aceitava ser tocada. Porém, no final do período de seis meses, já aceitava carinhos e os retribuía com reserva, de forma tímida, restringindo-se apenas a alguns professores e poucos colegas.

Como apontado na entrevista com a Supervisora Pedagógica que diz a respeito do marcante avanço no desenvolvimento da aluna: "Realmente houve um crescimento muito grande da Aline, uma menina que chegou por último na sala. Você vê a diferença marcante". Reafirmada pela Professora da Sala de Recursos. “(...) Aline hoje é outra criança, completamente adaptada”. Isso se deve à contribuição que a mediação afetiva proporciona, também abordada na descrição dos resultados, indicando que Aline está adaptada, incluída, respeitada e amada por todos.

Neste sentido, a afetividade: "refere-se à capacidade, à disposição do ser humano de ser afetado pelo mundo externo e interno por meio de sensações ligadas a tonalidades agradáveis ou desagradáveis" (MAHONEY e ALMEIDA, 2007, p. 17).

Nessa perspectiva da ideia de mediação ser a intermediação, de algo interposto entre uma coisa e outra e tendo como base a afetividade é que podemos evidenciar que a mediação afetiva proporcionou a Aline um ambiente de permanente desenvolvimento.

\subsection{Interação da aluna Aline}

A interação da aluna se dá em raros momentos de forma fragmentada. Interage a sua maneira, às vezes indiferente, sem demonstrar qualquer emoção ou envolvimento com a situação. Apesar de perceber o outro, não responde às interpelações sugeridas pelos colegas. 
Quando o colega a cumprimenta, dizendo: "Oi Aline!”, ela simplesmente não responde ou emite frases desconexas. Isso comprova o que os teóricos relatam como uma das características do indivíduo com transtorno do espectro autista.

Por outro lado, destaca-se o que Urbanski (2007, p.12) aponta:

Há evidências substanciais de que crianças com autismo engajam-se e respondem a interações sociais (Capps, Sigman \& Mundy, 1994); apresentam comportamentos afiliativos (ex: carinhos), vocalização em direção ao parceiro, participação em brincadeiras e comportamentos indicativos de apego (Capps e cols., 1994; Mundy \& Sigman, 1989). Apesar de se questionar a natureza recíproca desses comportamentos, a sua ocorrência ajuda a refutar a idéia de que uma criança com autismo evita, persistentemente, a interação social, conforme acreditava Richer (1976). Essas evidências apontam para a necessidade de revisão das noções referentes aos indicadores de autismo ainda no primeiro semestre de vida do bebê.

Assim, torna-se clara a diversidade em múltiplas dimensões do seu comportamento bem como o seu padrão de desenvolvimento. É nesta perspectiva que podemos nos apropriar das colocações de Tolezani (2010) ${ }^{9}$, quanto a condição de interação de um aluno TGD e suas possibilidades de comunicação:

\begin{abstract}
Enquanto nos juntamos à criança, permanecemos disponíveis para interagir com ela quando ela quiser e puder. Quando ela passa anos oferecer "sinais verdes para a interação", como por exemplo, olhando em nossa direção ou para o que estamos fazendo, olhando em nossos olhos, falando conosco, oferecendo algum contato físico, seu estado de disponibilidade está mudando e ela está agora interessada em nós e em nosso mundo. Aproveitamos esta oportunidade para tentarmos então criar alguma atividade interativa com ela, convidando-a para interagir conosco em uma atividade que possa ser interessante e divertida para ela. Enquanto a criança participa da atividade ou da brincadeira, inserimos metas educacionais personalizadas que ajudam a criança a aprender brincando. Quanto mais motivada a criança estiver entro da atividade, mais participações conseguiremos solicitar dela e, de uma forma divertida, incentivá-la a superar suas dificuldades e desenvolver suas habilidades. (Grifos da autora).
\end{abstract}

Desta forma, as limitações de Aline não implicam em seu isolamento, pois há interação, uma vez que respeitada seu ritmo e sua individualidade.

\title{
6.6 Limitações específicas da aluna Aline
}

9 TOLEZANI, Mariana. Son-Rise: Uma abordagem inovadora. In: Revista Autismo. Disponível em: http://revistaautismo.com.br/ Acessado em 02/04/2011. 
O quadro retrata a tipicidade específica e exclusiva de um autista por apresentar as seguintes limitações: padrões repetitivos de movimentos comportamentais; dificuldades no uso da linguagem oral; difícil relacionamento com pessoas, restrito apenas a alguns, de forma limitada e limitações na psicomotricidade.

No nosso caso, a aluna pegava um brinquedo geralmente em forma de animal, demonstrando ter fixação por esta categoria e repetindo os mesmos movimentos. Em relação à linguagem, a aluna pouco fala, e quando acontece, comunica-se de forma descontextualizada e sem nexo. De repente, no meio de uma atividade, fala frases soltas tais como "vai chover, vai chover" ou "preciso passar, preciso passar", sem que haja, aparentemente, relação com a atividade que está desenvolvendo.

Apresenta ainda difícil relacionamento com pessoas apesar de não procurar o isolamento, Apenas não há disposição para responder a interação. Utilizando a ponta dos pés. Atualmente, apesar de seu caminhar ser aparentemente normal, intercala o caminhar com leves saltos, como se fora uma bailarina.

Mais uma vez trazemos aqui as limitações elencadas por teóricos a partir de pesquisas já produzidas a cerca das limitações do indivíduo com TGD que também se apregoa a nossa Aline:

1.Dificuldade de comunicação - caracterizada pela dificuldade em utilizar com
sentido todos os aspectos da comunicação verbal e não verbal. Isto inclui gestos,
expressões faciais, linguagem corporal, ritmo e modulação na linguagem verbal. 2 .
Dificuldade de sociabilização - este é o ponto crucial no autismo, e o mais fácil de
gerar falsas interpretações. Significa a dificuldade em relacionar-se com os outros, a
incapacidade de compartilhar sentimentos, gostos e emoções e a dificuldade na
discriminação entre diferentes pessoas. 3. Dificuldade no uso da imaginação - se
caracteriza por rigidez e inflexibilidade e se estende às várias áreas do pensamento,
linguagem e comportamento da criança. Isto pode ser exemplificado por
comportamentos obsessivos e ritualísticos, compreensão literal da linguagem, falta de
aceitação das mudanças e dificuldades em processos criativos. (BRASIL, GUIA
PRÁTICO DO AUTISMO, 2001.)

Desta forma encontramos Aline com dificuldades na linguagem verbal e na comunicação apresentando ecolalia. Aline repete na íntegra, histórias e músicas inteiras mudando o tom de voz para diferenciar personagens ou falas.

A respeito da dificuldade de sociabilização, Mello (2001, p.14), aponta que:

Tal dificuldade faz com que a pessoa autista tenha uma pobre consciência da outra pessoa, é responsável, em muitos casos, pela falta ou diminuição da capacidade de imitar, que é um dos pré-requisitos cruciais para o aprendizado, e também pela dificuldade de se colocar no lugar do outro e de compreender os fatos a partir da perspectiva do outro. 
É verdade que Aline apenas imita as falas, porém este comportamento nos dá pistas para a potencialidade de Aline para o aprendizado e uma discreta motivação para socializarse. Neste momento é que podemos nos apropriar do conceito de zona do desenvolvimento proximal de Vygotsky (1987, p.97), uma vez que:

[...] A distância entre o nível de desenvolvimento real, que se costuma determinar através da solução independente de problemas, e o nível de desenvolvimento potencial, determinado através da solução de problemas sob a orientação de um adulto ou em colaboração com companheiros mais capazes.

É neste sentido que a intervenção do "outro social" como mediador proporcionou a Aline desenvolver-se em sua potencialidade. Portanto, há uma possibilidade real de desenvolver e romper com tais dificuldades é a creditação do inexorável papel da medição afetiva e da extrema importâmcia do outro dentro do processo de inclusão educativa de um aluno TGD.

\subsection{A participação do outro no processo de inclusão}

A participação do outro se dá de forma qualitativa e atuante, facilitando positivamente o processo de inclusão tornando-se referência positiva para Aline, uma vez que se percebe sensivelmente na aluna um maior desenvolvimento cognitivo e de interação social desde seu o início do processo de inclusão.

Segundo sugerem os dados coletados na entrevista a qual a professora regente faz referência a uma declaração da avó da aluna em que diz:

"O que eu poderia contribuir? Assim, o que eu vi, o que foi positivo foi o que a avó me disse, que ela sairia daqui com a posição de que a neta dela teve um ano tranqüilo, um ano positivo, um ano que ela viu seu processo de desenvolvimento predominante".

Os dados sugerem ainda o fortalecimento do outro social no ambiente escolar o qual é espaço privilegiado de interação social, pois possibilita a apropriação da diversidade cultural e aprendizagem de conteúdos, base para a constituição da pessoa em si e também do outro.

Assim, encontramos nos estudos de González Rey (2004, p.22) referencia quanto o significado do outro no processo de desenvolvimento.

O outro tem significação para o desenvolvimento só quando o sujeito consegue um relacionamento com esse outro, carregado de sentido, de modo que, se o vínculo de sentido subjetivo não se estabelece esse outro não será uma figura significativa para o desenvolvimento. Desde as etapas primeiras do desenvolvimento o outro aparece diferenciado pelo tipo de sentido que produz no sujeito com o qual interage. 
Portanto, o papel do outro social na superação das dificuldades de aprendizagem e no caso, de inclusão educacional, tem relevância significativa e status de mediador propulsor das potencialidades do indivíduo. O outro é um sujeito ativo, concreto que atua em sistemas históricos complexos da atividade interativa. 


\section{VII- CONSIDERAÇÕES FINAIS}

Retomando o objetivo desta pesquisa os dados permitiram compreender como a mediação afetiva pode contribuir para o processo de inclusão educacional de um aluno com Transtorno Global do Desenvolvimento.

Para tanto, estabelecemos metas específicas para alcançar respostas a esse objetivo. Assim, identificou-se que a contribuição da mediação afetiva entre professor e aluno constitui um divisor de águas, a qual se abre para o desenvolvimento das potencialidades do aluno em processo de inclusão.

Em relação à interação da aluna com seus pares, evidenciaram-se aspectos interacionais e culturais numa perspectiva dialética onde o outro se transforma e desenvolve e também é modificado a partir dessa relação.

Já no tocante às limitações específicas da aluna dificultando ou não a troca afetiva, verificou-se que tais limitações apresentam-se como um entrave no processo de inclusão, porém, não restringe sua iniciativa, meio que tímida, de relacionar-se com o ambiente, quando é, por assim dizer, respeitada em sua individualidade e entendida que sua afetividade é expressa a sua maneira.

Quanto à mediação pedagógica utilizada pela docente para possibilitar a interação do TGD com o ambiente e o outro, identificou-se que a flexibilidade de seu planejamento acarreta em possibilidades de avanços e adequações pedagógicas levando sempre em consideração o olhar do outro e para o outro, no caso específico, as necessidades reais de Aline.

Tendo em vista tais objetivos, chega-se a seguinte resposta para a pergunta inicial: a mediação afetiva contribui significativamente com o processo de inclusão educacional de alunos com TGD, pois o que se caracteriza como aspecto negativo dentro de um quadro de espectro autista, ou seja, a dificuldade nas relações e trocas afetivas, é que justamente justifica ações interativas que possibilitem seu desenvolvimento. Com este estudo podemos apreender que o processo de inclusão da aluna torna-se efetivo a partir das trocas afetivas e da participação do outro, o qual compõe o cenário da Aline de maneira bem particular, pois é a partir dele que ela se mostra e se constitui. 
Sendo assim, acredito que esta pesquisa tentou mostrar que o processo de inclusão de alunos com transtorno global do desenvolvimento é possível a partir da mediação afetiva, e desse modo, contribuir para que educadores invistam na mediação afetiva como alavanca para o real processo de inclusão educacional. 


\section{REFERÊNCIAS}

ALMEIDA, Ana Rita. S. A emoção na sala de aula. 4.Ed. Campinas: Papirus, 2004.

BLANCO, Rosa. A atenção à diversidade na sala de aula e as adaptações ao currículo. In: COLL, C.; MARCHESI, A.; PALACIOS, J. (org.). Desenvolvimento psicológico e educação: transtornos do desenvolvimento e necessidades educativas especiais. 2.Ed. Porto Alegre: Artmed, 2004. 3v.

BRASIL, Cadernos Especiais. Brasília: CORDE, 1994.

BRASIL, Educação Especial. Brasília: SEESP, 1994.

BRASIL, Mec,UNESCO. Declaração de Salamanca e Linha de Ação sobre Necessidades Educativas. Disponível em www. portal.mec.gov.br/seesp/arquivos/pdf/salamanca.pdf.

BRASIL, Ministério da Educação. Secretaria de Educação Especial. Política Nacional de Educação Especial. 2007. Disponível em: <http://www.campusoei.org/calidad/aguerrondo.htm> Acesso em: 04 mar. 2011.

DAMÁSIO, Antonio. O erro de Descartes: emoção, razão e o cérebro humano. 2.Ed. São Paulo: Companhia das Letras, 2006.

GALVÃO, Izabel. Henri Wallon: uma concepção dialética do desenvolvimento infantil. 2. Ed. Petrópolis: Vozes, 1995.

GLAT, R. A Integração Social dos Portadores de Deficiência: uma Reflexão. Rio de Janeiro: Editora Sette Letras, 1995.

GUTIERREZ, Francisco. Linguagem total: uma pedagogia dos meios de comunicação. São Paulo: Summus, 1978.

LA TAILlE,Yves. Piaget, Vygotsky, Wallon: Teorias Psicogenéticas em Discussão. São Paulo: Summus, 1992.

MARTINS, Alice F. As artes visuais e a educação inclusiva. In: Arte sem barreiras. Educação - Arte - Inclusão. Edição Especial. Anais do $1^{\circ}$ Congresso Internacional, 2002, v.1. 
MARTINS, Miriam C, PICOSQUE, Gisa; GUERRA, Terezinha T. Didática do ensino da arte: a língua do mundo. Poetizar, fruir e conhecer arte. São Paulo: FTD, 1998.

MESIBOV,Gary. SHEA, Victoria. Full inclusion and students with autism. Journal of Autism and Developmental Disorders. Vol. 26, N. 3, 2005. Disponível em: www.scielo.br/pdf/rbedu/v11n33/a02v1133.pdf, acessado em 02/03/2011

PIAGET, J. e GRECO, P. Aprendizagem e conhecimento. São Paulo: Freitas Bastos, 1974.

PIAGET, J. Seis estudos em psicologia. Rio de Janeiro: Forense. 1978.

Para onde vai a educação? Rio de Janeiro, Olympio - Unesco, 1973.

PILLAR, Analice D. A educação do olhar no ensino da arte. In: BARBOSA, Ana Mae (org.). Inquietações e mudanças no ensino da arte. São Paulo: Cortez, 2002, p.71-82.

REGO, T.C. Vygotsky: Uma perspectiva histórico-cultural da educação. Petrópolis: Resumidos e comentados por Ana Maria S. Rosa de Mello e Rebeca Costa e Silva.

RICHTER, Sandra. A arte e a dimensão poética do conhecer na infância. In: Projeto Revista de Educação: Artes Plásticas. Porto Alegre: Projeto, v.3, n.5, 2001, p. 20-27.

SASSAKI, R. K. Inclusão: Construindo uma Sociedade para Todos. Rio de Janeiro:1997.

SCHWARTZMAN, José Salomão. Síndrome de Down e Transtorno Global do Desenvolvimento São Paulo: Mackenzie: 1999

URBANSKI, Luiz. Universo Autista - um mundo a descobrir, Revista eletrônica. Disponível em: http://www.universoautista.com.br/autismo/. Acesso em março de 2011.

VYGOTSKY, Lev S. A formação social da mente. São Paulo: Martins Fontes, 1989.

WERNECK, Claudia. Ninguém mais vai ser bonzinho na sociedade inclusiva. WVA,1997. 
APÊNDICES 


\section{Apêndice A - Roteiro de Entrevista - Docente}
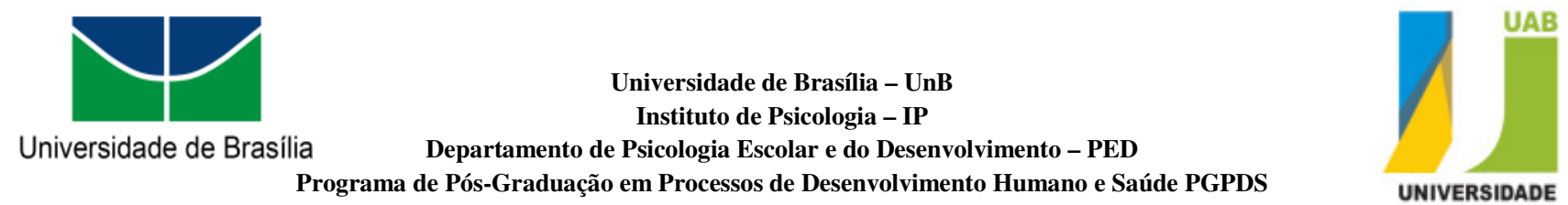

Programa de Pós-Graduação em Processos de Desenvolvimento Humano e Saúde PGPDS

Curso de Especialização em Desenvolvimento Humano. Educação e Inclusão Escolar Módulo VIII - Orientação da Monografia

Pólo Ceilândia B

Aluna: Érika Goulart Araújo

\section{ENTREVISTA \\ Docente}

1 - Entrevista:

Nome:

Sexo:

Função:

1.1 Tempo de Atuação na Educação:

1.2 Tempo de atuação na Educação com aluno TGD:

1.3 Formação profissional:

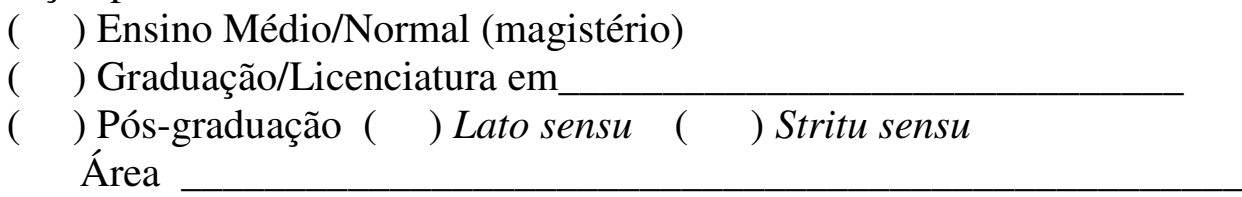

Cursos de aperfeiçoamento

1.4- Como avalia sua relação com o aluno TGD?

1.5- O que considera positivo nesta relação?

1.6- $\mathrm{O}$ que pensa ou necessita mudar para atender seu aluno TGD?

1.7 - Quais as dificuldades encontradas por você no processo de inclusão desse aluno?

1.8 - Você recebe assessoramento para o desempenho de suas atividades pedagógicas em relação ao aluno TGD? Com que frequência?

1.9- Considera seu ambiente de sala de aula de acordo com a metodologia utilizada?

1.10- Os outros alunos se dispersam como aluno TGD Em quais situações? 


\section{Apêndice B - Roteiro de Observação}
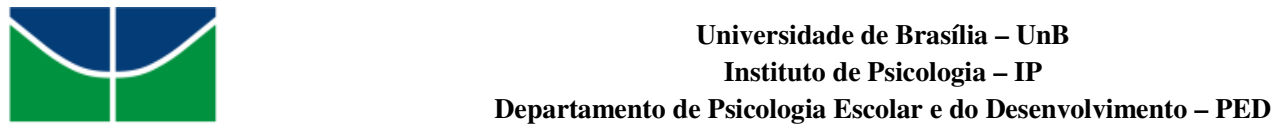

Curso de Especialização em Desenvolvimento Humano. Educação e Inclusão Escolar Módulo VIII - Orientação da Monografia

Pólo Ceilândia B

Aluna: Érika Goulart Araújo

\section{ROTEIRO DE OBSERVAÇÃO}

Aspectos a serem observados:

1. SALA DE AULA

2- Planejamento pedagógico

3- Desenvolvimento das atividades pedagógicas

4- Atendimentos individualizados

5- Resolução de conflitos

6- Interação com os alunos

7- Interação com o aluno TGD

8- Comunicação com o aluno TGD

9- Atendimento ao aluno TGD

10- Mediação afetiva 


\section{Apêndice C - Roteiro de Observação - Aluno TGD}

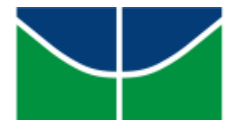

Universidade de Brasilia
Universidade de Brasília - UnB

Instituto de Psicologia - IP

Departamento de Psicologia Escolar e do Desenvolvimento - PED

Programa de Pós-Graduação em Processos de Desenvolvimento Humano e Saúde PGPDS

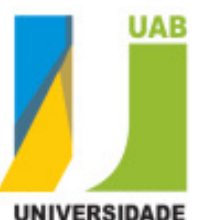

UNIVERSIDADE

Curso de Especialização em Desenvolvimento Humano. Educação e Inclusão Escolar Módulo VIII - Orientação da Monografia

Pólo Ceilândia B

Aluna: Érika Goulart Araújo

\section{Roteiro de Observação Aluno TGD}

Aspectos a serem observados:

1. Interação entre os pares

2. Interação com o professor

3. Relacionamento com a comunidade escolar

4. Execução das atividades propostas

5. Posicionamento em sala

6. Conta com monitor - relacionamento, comunicação 
Apêndice D - Roteiro de Observação - Aspectos físicos e estruturais

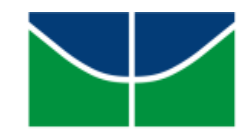

Universidade de Brasilia
Universidade de Brasília - UnB Instituto de Psicologia - IP

Departamento de Psicologia Escolar e do Desenvolvimento - PED

Programa de Pós-Graduação em Processos de Desenvolvimento Humano e Saúde PGPDS

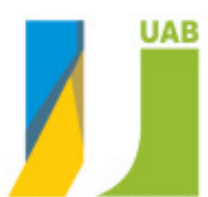

UNIVERSIDADE UNIVERSIDADE

Curso de Especialização em Desenvolvimento Humano. Educação e Inclusão Escolar Módulo VIII - Orientação da Monografia

Pólo Ceilândia B

Aluna: Érika Goulart Araújo

\section{Roteiro de Observação}

Aspectos físicos e estruturais

Aspectos a serem observados:

1. Acessibilidade física quantas, quais ou necessárias

2. Mobiliário em sala de aula

3. Banheiro

4. Pátio

5. Refeitório

6. Outros espaços 


\section{Apêndice E - Roteiro de Observação - Material Pedagógico}

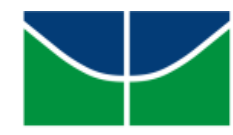

Universidade de Brasilia
Universidade de Brasília - UnB Instituto de Psicologia - IP

Departamento de Psicologia Escolar e do Desenvolvimento - PED

Programa de Pós-Graduação em Processos de Desenvolvimento Humano e Saúde PGPDS

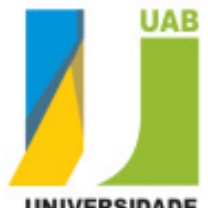

UNIVERSIDADE ABERTA DO BRASIL.

Curso de Especialização em Desenvolvimento Humano. Educação e Inclusão Escolar Módulo VIII - Orientação da Monografia

Pólo Ceilândia B

Aluna: Érika Goulart Araújo

\section{Roteiro de Observação Material Pedagógico}

Aspectos a serem observados:

1. Material utilizado

2. Materiais adaptados

3. Tecnologia assistiva

4. Recursos diferenciados em sala para atendimento individualizado 
ANEXOS 


\section{Anexo A - Termo de Consentimento Livre e Esclarecido - Pais}

Universidade de Brasília - UnB

Instituto de Psicologia - IP

Departamento de Psicologia Escolar e do Desenvolvimento - PED

Curso de Especialização em Desenvolvimento Humano, Educação e Inclusão Escolar

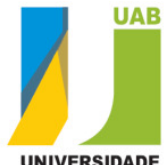

\section{TERMO DE CONSENTIMENTO LIVRE E ESCLARECIDO}

Senhores Pais ou Responsáveis,

Sou orientanda do Curso de Especialização em Desenvolvimento Humano, Educação e Inclusão Escolar, realizado pelo Instituto de Psicologia por meio da Universidade Aberta do Brasil- Universidade de Brasília (UAB-UnB) e estou realizando um estudo sobre Transtorno Global do Desenvolvimento e Afetividade no Processo de Inclusão Educacional. Este estudo poderá fornecer às instituições de ensino subsídios para o planejamento de atividades com vistas à promoção de condições favoráveis ao pleno desenvolvimento dos alunos em contextos inclusivos e, ainda, favorecer o processo de formação continuada dos professores nesse contexto de ensino.

Constam da pesquisa observações das situações cotidianas e rotineiras da escola, próprias das NEEs , INCLUSÃO e, ainda, entrevistas semi estruturadas com os professores no intuito de e sua interação com o aluno TGD.

Para isso, solicito sua autorização para que sua filha participe do estudo.

Esclareço que a participação no estudo é voluntária. Sua filha poderá deixar a pesquisa a qualquer momento que desejar e isso não acarretará qualquer prejuízo ou alteração dos serviços disponibilizados pela escola. Asseguro-lhe que a identificação de sua filha não será divulgada em hipótese alguma e que os dados obtidos serão mantidos em total sigilo, sendo analisados coletivamente.

Caso tenha alguma dúvida sobre o estudo, a senhora poderá me contatar pelo telefone 61-9973.4482 ou no endereço eletrônico erikagoulart@hotmail.com. Se tiver interesse em conhecer os resultados desta pesquisa, por favor, indique um e-mail de contato.

Agradeço antecipadamente sua atenção e colaboração.

Respeitosamente,

Orientanda(o) do Curso de Especialização em Desenvolvimento Humano, Educação e Inclusão Escolar UAB UnB

Sim, autorizo a participação de minha filha

neste estudo.

Nome:

Assinatura:

E-mail (opcional): 


\section{Anexo B - Termo de Consentimento Livre e Esclarecido - Professores}

Universidade de Brasília - UnB

Instituto de Psicologia - IP

Departamento de Psicologia Escolar e do Desenvolvimento - PED

Curso de Especialização em Desenvolvimento Humano, Educação e Inclusão Escolar

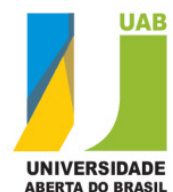

TERMO DE CONSENTIMENTO LIVRE E ESCLARECIDO

Senhores Professores,

Sou orientando do Curso de Especialização em Desenvolvimento Humano, Educação e Inclusão Escolar, realizado pelo Instituto de Psicologia por meio da Universidade Aberta do Brasil- Universidade de Brasília (UAB-UnB) e estou realizando um estudo sobre Transtorno Global do Desenvolvimento e Afetividade no Processo de Inclusão Educacional. Este estudo poderá fornecer às instituições de ensino subsídios para o planejamento de atividades com vistas à promoção de condições favoráveis ao pleno desenvolvimento dos alunos em contextos inclusivos e, ainda, favorecer o processo de formação continuada dos professores nesse contexto de ensino.

Constam da pesquisa observações das situações cotidianas e rotineiras da escola, próprias das NEEs , inclusão e, ainda, entrevistas semi estruturadas com os professores no intuito de e sua interação com o aluno TGD. Para isso, solicito sua autorização para participação no estudo.

Esclareço que a participação no estudo é voluntária. Você poderá deixar a pesquisa a qualquer momento que desejar e isso não acarretará qualquer prejuízo a você. Asseguro-lhe que sua identificação não será divulgada em hipótese alguma e que os dados obtidos serão mantidos em total sigilo, sendo analisados coletivamente.

Caso tenha alguma dúvida sobre o estudo, a senhora poderá me contatar pelo telefone 61-9973.4482 ou no endereço eletrônico erikagoulart@hotmail.com. Se tiver interesse em conhecer os resultados desta pesquisa, por favor, indique um e-mail de contato.

Agradeço antecipadamente sua atenção e colaboração.

Respeitosamente,

Orientanda do Curso de Especialização em Desenvolvimento Humano, Educação e Inclusão Escolar UAB UnB

Concorda em participar do estudo? ( ) Sim ( ) Não

Nome:

Assinatura:

E-mail (opcional): 